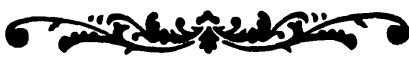

\title{
PETRARCHAN PROBLEMATICS: TRADITION AND THE INDIVIDUAL CULTURE
}

$\mathrm{P}$ etrarchism, itself a discourse of extremes, demands from its critics a rhetoric of qualifications and modulations. For lyrics in this tradition resist easy generalizations as determinedly as Laura flees her Apollo: their meaning is as tantalizingly veiled as her face, as evanescent as the snow that so often figures her. The tradition not only stages but also represents a series of paradoxes; its poems are, for example, more likely than texts in many other genres to be either singularly conventional or strikingly transgressive or both, and they may variously celebrate and subvert ideologies of gender. More to our purposes here, the reception of these lyrics was no less paradoxical than their own agendas: they enjoyed an extraordinary vogue throughout much of Europe yet endured repeated attacks from the very cultures and poets who seemed most enamored of them.

Petrarch's love poems are particularly liable to problems in interpretation. Critics part company on the most basic issues: Is their fundamental aim the praise of the lady, as some scholars of an earlier generation assumed, or the establishment of the poet's own subjectivity, as many of their contemporary counterparts would assert?' Is the final poem the culmination of a movement towards spiritual resolution or an instance of the ways that movement has been compromised throughout the sequence? ${ }^{2}$ The rhetoric of the

${ }^{1}$ For instances of these positions, see, respectively, Leonard Forster, The Icy Fire: Five Studies in European Petrarchism (Cambridge: Cambridge University Press, 1969), esp. p. 9; and Gordon Braden, "Love and Fame: The Petrarchan Career," in Pragmatism's Freud: The Moral Disposition of Psychoanalysis, ed. Joseph H. Smith, M.D., and William Kerrigan (Baltimore: Johns Hopkins University Press, 1986).

${ }^{2}$ Many critics have espoused each of these positions; for example, see, respectively, Mar- 
lyrics thwarts efforts to resolve these and other debates. From the very opening of the Rime sparse, Petrarch qualifies and undermines his statements: "quand' era in parte altr' uom da quel ch'i'sono" (I.4, emphasis added; "when I was in part another man from what I am now"). ${ }^{3}$ As the sequence progresses, terms like forse (perhaps) and forms of the verb parere (to seem) repeatedly destabilize declarative statements. It is no accident that these poems have attracted and rewarded deconstructive analyses. ${ }^{4}$

Far from resolving such paradoxes, Petrarch's early commentators have confounded them, as we have already observed. ${ }^{5}$ Similarly, Petrarch's imitators repeatedly construct different versions of both the type of Petrarchism they are writing and the type they are eschewing. As Roland Greene acutely demonstrates, all sonnets after the Rime sparse are "post-Petrarchan" in that they reinterpret their heritage. ${ }^{6}$ Nor have contemporary critics achieved a consensus. Witness, for example, the gap between Marjorie O'Rourke Boyle's claim that the Canzoniere exemplify the theological and spiritual values expressed elsewhere in the canon,? Aldo S. Bernardo's assertion that the Triumphs achieve the fusion of the classical and heavenly for which Petrarch has striven with varied success in the Rime sparse, ${ }^{8}$ and John Freccero's contrast between Augustine's spirituality and Petrarch's fallen vision. ${ }^{9}$

Generalizing about Petrarchan love is, then, almost as perilous as prac-

jorie O'Rourke Boyle, Petrarch's Genius: Pentimento and Prophecy (Berkeley: University of Califomia Press, 1991), esp. p. 149; and Robert M. Durling, The Figure of the Poet in Renaissance Epic (Cambridge: Harvard University Press, 1965), pp. 83-84.

${ }^{3}$ All citations and translations from Petrarch's Rime sparse are to Petrarch's Lyric Poems: The Rime sparse and Other Lyrics, ed. and trans. Robert M. Durling (Cambridge: Harvard University Press, 1976). The play on "in parte" is also noted by Sara Sturm-Maddox in Petrarch's Laurels (University Park: Pennsylvania State University Press, 1992), p. 232. For a different but compatible reading of the instability of Petrarch's language, see William J. Kennedy, Authorizing Petrarch (Ithaca: Cornell University Press, 1995), esp. pp. 5-24.

${ }^{4}$ See esp. Marguerite Waller, Petrarch's Poetics and Literary History (Amherst: University of Massachusetts Press, 1980).

${ }^{5}$ See esp. two studies by William J. Kennedy: Authorizing Petrarch, and "Petrarchan Textuality: Commentaries and Gender Revisions," in Discourses of Authority in Medieval and Renaissance Literature, ed. Kevin Brownlee and Walter Stephens (Hanover, N.H.: University Press of New England, 1989).

${ }^{6}$ Roland Greene, Post-Petrarchism: Origins and Innovations of the Western Lyric Sequence (Princeton: Princeton University Press, 199I).

'Boyle, Petrarch's Genius.

${ }^{8}$ Aldo S. Bernardo, Petrarch, Laura, and the Triumphs (Albany: State University of New York Press, 1974).

'John Freccero, "The Fig Tree and the Laurel: Petrarch's Poetics," in Literary Theory/ Renaissance Texts, ed. Patricia Parker and David Quint (Baltimore: Johns Hopkins University Press, 1986). 
ticing it. In this chapter I counter such risks partly by delimiting my own agenda: I aim not to survey the entire tradition but to anatomize the particular characteristics that help to explain why Petrarch inspired both so many imitations and so many correctives in sixteenth- and seventeenthcentury England. And I concentrate mainly on Petrarch himself, though at several junctures I develop or qualify generalizations about him by alluding to other Continental writers. The influence of French poets on the English sonnet tradition was profound, pervasive, and protean, as Anne Lake Prescott has shown: Gorges translates texts by Du Bellay, Ronsard, and Desportes, four poems in Daniel's Delia are based on sonnets to Du Bellay's Olive; Lodge borrows entire lyrics from Ronsard; and so on. ${ }^{10}$ In I 594 , when decrying slavish imitation in the dedicatory poem of Ideas Mirrour, Drayton mentions Desportes as well as Petrarch. Yet the author of the Rime sparse is, after all, still the main influence on English Petrarchism, and discussions of English Petrarchism can profitably ground generalizations in a detailed analysis of his work.

In the end, all the cautions and caveats demanded by a study of Petrarchism enrich, not endanger, that enterprise. For the problems of interpretation and representation exemplified by that tradition are central to its attractiveness and its agendas in the English Renaissance. ${ }^{11}$ Those challenges help us to address the central question about Tudor and Stuart culture on which this chapter pivots: Why does Petrarchism attract both so many adherents and so many detractors, inspire slavish imitations and embittered rejections? While some answers to those questions are predictable and familiar (Petrarchism clearly did offer intriguing technical challenges and an arena for nationalistic pride and competitiveness), other answers will involve a radical reinterpretation of both Petrarchism itself and the culture, or rather cultures, of Tudor and Stuart England. In particular, analyzing responses to English Petrarchism reveals the conjunctions between that international literary discourse and more local problems. These patterns emerge most clearly when we approach the movement from five interrelated perspectives: the movement between success and failure, the nature of narrative and lyric, the dangers of repetition, the problems of gender, and the drive to differentiate.

\footnotetext{
${ }^{10}$ Anne Lake Prescott, French Poets and the English Renaissance: Studies in Fame and Transformation (New Haven: Yale University Press, 1978).

${ }^{11}$ Other critics have noted that the problems of interpretation are central to the meaning of these poems. See, e.g., Guiseppe Mazzotta's analyses of the instability of both language and desire ("The Canzoniere and the Language of the Self," SP, 75 [1978], 271-296; reprinted in The Worlds of Petrarch [Durham, N.C.: Duke University Press, 1993]).
} 
Sonnet I 8 is neither one of the best known lyrics in the Canzoniere nor one of the best, but it is typical of the collection in ways germane to those five perspectives and hence to the reception and reinterpretation of $\mathrm{Pe}-$ trarchism in England.

Rimansi a dietro il sestodecimo anno
de' miei sospiri, et io trapasso inanzi
verso l'estremo; et parni che pur dianzi
fosse 'l principio di cotanto affanno.

L'amar m'è dolce, et util il mio danno, e 'l viver grave; et prego che gli avanzi l'empia fortuna; et temo no chiuda anzi Morte i begli occhi che parlar mi fanno.

Or qui son, lasso, et voglio esser altrove, et vorrei più volere, et più non voglio, et per più non poter fo quant' io posso;

et d'antichi desir lagrime nove provan com' io son pur quel ch' i' mi soglio, né per mille rivolte ancor son mosso.

(Now remains behind the sixteenth year of my sighs, and I move forward toward the last; yet it seems to me that all this suffering began only recently. The bitter is sweet to me, and my losses useful, and living heavy; and I pray that my life may outlast my cruel fortune; and I fear that before then Death may close the lovely eyes that make me speak. Now here I am, alas, and wish I were elsewhere, and wish I wished more, but wish no more, and, by being unable to do more, do all I can; and new tears for old desires show me to be still what I used to be, nor for a thousand turnings about have I yet moved.)

Characteristically preoccupied with time, Petrarch here plays several conflicting interpretations of it against one another. The opening line introduces an objective chronological sequence by alluding to years that can be measured-yet "parmi" ( 3 ; "it seems to me") signals a subjective time sequence at variance with the first one. Moreover, lines seven to eight introduce a mode of time which was to prove particularly significant in 
the work of Petrarch's English imitators: allusions to the future, a realm that may be variously associated with uncontrolled fears or soaring hopes, with the authority of the successful prophet or, as in this case, the helplessness of the fearful prognosticator.

In any event, all these time schemes are contrasted with the psychological stasis that is the most significant temporal mode of these texts. Thus "d'antichi desir lagrime nove / provan com' io son pur quel ch' i' mi soglio" (12-13; "and new tears for old desires show me to be still what I used to be") starts on an antithesis that seems firmly to establish the then/ now pattern that Roland Greene rightly claims is central to the sequencebut that pattern is blurred by the admission that in the psyche of the speaker, then and now collide and elide. ${ }^{12}$ As the conclusion of the poem indicates, for all the volatility of his emotions, he moves without moving. But this paradox was in fact anticipated in lines nine through eleven, where the traductio associated with volere (to wish) and potere (to be able) rhetorically stages the conjunction of change and its lack to which the concluding lines refer more overtly. Those reduplicated verb forms demonstrate how rhetorical repetition can figure the many types of entrapment that Petrarchism involves, the "thousand turmings" that fail to produce movement. Stasis is the physical state that represents an emotional state of depression and compulsive repetition, of wishing that one was not unable even to wish.

That paradox prepares us for the approach to agency in this lyric and elsewhere in the sequence as well. On the one hand, for all his frustration, on some level Petrarch is in charge of his medium. Even though Laura speaks often, in several ways he has the last word. And he also has a kind of autonomy that Laura, who is present in the poem only in terms of her effects on him, lacks. On the other hand, line eight reminds us that his speech is generated elsewhere, in her eyes. Such lines should not be dismissed with the claim that the woman is merely assuming gendered roles that in fact figure her subordination, such as the Muse. Indeed, to redeploy Margaret Homans's phrase, it is the male poet who bears the word of another. ${ }^{13}$ Hence one cannot preserve the critical commonplace of the masterful Petrarchan poet by arguing that, despite the unruliness of his emotions, his power and agency reside in his skillful deployment of language: his poetic gifts are as much a source and symptom of his problems as a solution to them.

Yet neither is Laura's agency uncompromised; if she can make the poet

${ }^{12}$ Greene, Post-Petrarchism, esp. pp. 33-34.

${ }^{13}$ Margaret Homans, Bearing the Word: Language and Female Experience in Nineteenth-Century Women's Writing (Chicago: University of Chicago Press, 1986). 
speak, Death, he fears, will close her eyes and hence stifle one source of her potency. Indeed, the grammatical structures of "et temo no chiuda anzi / Morte i begli occhi che parlar mi fanno" (7-8; "and I fear that before then Death may close the lovely eyes that make me speak") body forth this paradoxical power structure: Laura's eyes are poised on the hinge of a phrase, variously object and subject, a double role that mimes the ambiguities of the speaker's own agency. ${ }^{14}$ In this as in so many other ways they are twinned: if Laura is both subject and object in the sentence, thus eliding the two roles, so too do Petrarch and Laura, the figures who are normally interpreted as the antithetical subject and object of love poetry, themselves elide. $^{15}$

In this lyric, then, we repeatedly encounter the poet's slide between mastery and loss, the temporal patterns that often figure it, and a related slippage, the instability of gender. Thus Poem I 8 introduces some of the five conflicts in Petrarchism on which this chapter focuses-success versus failure, narrative versus lyric, repetition versus closure or stasis, masculine versus feminine, and differentiation versus sameness - as well as the elisions that typically recur in those areas. Or, to put it another way, this and many other texts in the Rime sparse enact and interpret dramas about male subjectivity and its relationship to gender like those that were to be played in many of the theaters, literal and metaphoric, of sixteenth-century England.

Although many readers have noted that the Rime sparse repeatedly resorts to the trope of the pilot, Petrarch's deployment of that metaphor deserves more scrutiny, not least because it represents the careening relationship between success and failure in the sequence. Sometimes the speaker himself is the pilot; sometimes, as in Sonnet I89 ("Passa la nave"), which inspired several English imitations, Petrarch is merely a passenger in a ship steered by his enemy. And even in the lyrics where he takes over the rudder, he is by no means assured of retaining his control of it: this is a pilot who, overwhelmed by storms or by the lady, repeatedly loses the ability to steer.

\footnotetext{
${ }^{14}$ Compare Ilona Bell's observations about a male pronoun Milton uses when recounting Eve's creation ("Milton's Dialogue with Petrarch," Milton Studies, 28 [1991], 100).

${ }^{15}$ Many critics have noted these elisions. For a particularly thought-provoking reading of them, different from but compatible with my own, see Marguerite Waller, "Historicism Historicized: Translating Petrarch and Derrida," in Historical Criticism and the Challenge of Theory, ed. Janet Levarie Smarr (Urbana: University of Illinois Press, 1993), pp. 192-204. I thank the author for making this text available to me before publication.
} 
Sonnet 235 juxtaposes statements that themselves seem paradoxical, driven off course: first the speaker admits that he is carried off against his will by love, then celebrates his ability to protect his ship from the lady, and then admits that the weather has buffeted that vessel to the point where it lacks sails and tiller. Similarly, as we saw, Sonnet ISI opens by comparing the lover to a pilot fleeing a wave, a comparison subverted by the "Non" on which the lyric begins. (As that negative reminds us, Petrarch resembles Herrick, a fellow student and victim of desire, loss, and their connections, in that in the text of both poets, presence is repeatedly promised, then denied.) Thus the pilot who ostensibly controls his ship yet is often driven astray draws our attention to storm systems in the epistemological and psychological climate of this sequence. Like the speaker in the poem by Watson on which this book opened, its lover is tossed back and forth between success and failure as both a poet and a lover, as well as between more specific manifestations of those states: agency and its absence, mastery and loss of control.

Our current professional preoccupations may at times tempt us to neglect one source of the Petrarchan poet's success and mastery: solving formal problems. I am not denying that the construction of and participation in an aesthetic realm are necessarily implicated in cultural agendas. But that recognition need not preclude tracing the workings of technical virtuosity. In the case at hand, when the Petrarchan pilot does manage to steer his nautological craft, he does so in no small part by displaying and practicing his aesthetic craft: the skill involved in mastering a sestina or playing on a small number of rhymes or weaving into one's own text lines written by one's predecessors is a source and symbol of achievement. If the rhetorical agenda of Petrarchism often is announcing one's failure as a lover or that of the alter ego one invokes, the aesthetic agenda frequently includes manifesting and celebrating one's success as a poet. Yet that agenda may be undermined in many ways in the course of the poem. English Petrarchism and its counterdiscourses recur repeatedly to these paradoxes.

Most obviously, writing poetry, pursuing the laurel, represents both success and failure. In the Rime sparse, as in the Coronation Ode, the achievements of the poet are often celebrated; but Petrarch never allows us to forget the Augustinian distrust of the imagination, and he repeatedly suggests that his own verse may misrepresent what it claims to describe and that his readers may in turn misunderstand what they claim to interpret or even refuse to believe what they read. While the inexpressibility conceit is a literary commonplace, all these other references to the limitations of the poet's power ensure that it is resonant on the many occasions when Petrarch himself invokes it. As Guiseppe Mazzotta, one of the most acute 
students of Petrarch, points out, achieving a vision of the beloved is, paradoxically, associated with losing one's voice. ${ }^{16}$ Nor is regaining that voice an unmixed blessing, for speech in general and poetic speech in particular are fraught with danger as presented by Petrarch. In Poem 23, one of his most revealing texts, he is identified with Battus, whose transgression is speaking; ${ }^{17}$ as Francesco learns in the Secretum, one of the chains that binds him is the love of glory, including the glory achieved by the poet. Poem 239 is a sestina that rings the changes on versi (verses) and note (notes) and in so doing reminds us how those manifestations of the poetic impulse can lend themselves to both positive and negative valuations. Given these contradictory judgments on poetry, it is no wonder that Petrarch so often invokes Orpheus, another multivalent poet, who in medieval and Renaissance commentaries variously represented everything from Christ to the eloquent lover to the dangers of base passions. ${ }^{18}$

The frustrated wandering to which Petrarch refers so often in his love lyrics, as well as his epistle about the ascent of Mount Ventoux, aptly figures the paradoxical presentation of agency in this sequence: wanderers have some control over their movements, but they experience difficulty when they attempt, as it were, to climb the mountain as they had hoped. Similarly, witness the paradoxical treatment of agency in the well known lines of Sonnet 5 :

vostro stato RE-al che 'ncontro poi raddoppia a l'alta impresa il mio valore; ma "TA-ci," grida il fin, "ché farle onore è d'altri omeri soma che da' tuoi."

Così LAU-dare et RE-verire insegna la voce stessa,

(5.5-Io; Your RE-gal state, which I meet next, redoubles my strength for the high enterprise; but "TA-lk no more!" cries the ending, "for to do her honor is a burden for other shoulders than yours." Thus the word itself teaches LAU-d and RE-verence.)

${ }^{16}$ Mazzotta, "The Canzoniere and the Language of the Self," p. 278.

${ }^{17}$ Compare Leonard Barkan, The Gods Made Flesh: Metamorphosis and the Pursuit of Paganism (New Haven: Yale University Press, 1986), p. 21 I.

${ }^{18}$ On the varied interpretations of Orpheus, see John Block Friedman, Orpheus in the Middle Ages (Cambridge: Harvard University Press, 1970). 
While this text ostensibly celebrates the poet's skill in crafting anagrams with Laura's name, in much of the poem his agency is denied or deflected.

As I have emphasized, English poets often approached Petrarch's lyrics through the filters of both commentators and Continental poets. The latter group was to reinterpret his slippages between agency and its absence and between triumph and its opposite in varied and often contradictory ways. Although Petrarch's Rime sparse embodies a struggle between assertions of success and admissions of failure, the balance tilts towards the latter; that is not invariably the case in the work of later Petrarchan poets. The emphasis on fame in the texts of many French sonneteers is one source of this difference; on occasion they celebrate their achievements in a tone foreign to Petrarch himself. Ronsard, for example, sometimes exhibits a confidence that borders on arrogance, a note seldom present in Petrarch. Witness, for example, the declaration in the poem that opens the first book of Sonnets pour Hélène: "Je suis de ma fortune auteur" (I.I2; "I am author of my destiny"). ${ }^{19}$ Similarly, his "Elégie a son livre" defies not only women but also the poet's audience, which he often engaged in conflict. Yet, for all his defiance, even Ronsard admits to despair and powerlessness on occasion; in the poem immediately following that boast about his sovereignty over fortune, for example, he acknowledges that Hélène's cruelty induces such fear that he dare not speak, a confusion that anticipates the loss of agency in the work of many English poets.

This tempestuous tossing back and forth between representations of success and failure, agency and impotence, and control and helplessness is, then, at the core of Petrarch's poetry and that of many of his followers as well. And it should be at the core of our interpretations. Such upheavals have been acknowledged in some quarters, particularly by comparatists and Italianists: Thomas M. Greene has offered an especially incisive survey of the tensions within the Petrarchan speaker, noting as I do struggles between mastery and helplessness. ${ }^{20}$ And a few important studies have described similar patterns within certain English sequences. ${ }^{21}$ Yet critics from a range

${ }^{19}$ The citation is to Pierre de Ronsard, Les Amours, ed. Albert-Marie Schmidt and Françoise Joukovsky (Paris: Gallimard, 1974).

${ }^{20}$ In The Light in Troy: Imitation and Discovery in Renaissance Poetry (New Haven: Yale University Press, 1982), esp. chaps. 6 and 7, Thomas M. Greene acutely describes Petrarch's slippage between success and failure, though many of his conclusions differ from mine. I am indebted to his work throughout this chapter.

${ }^{21}$ See, e.g., Clark Hulse, "Stella's Wit: Penelope Rich as Reader of Sidney's Sonnets," in Rewriting the Renaissance: The Discourses of Sexual Difference in Early Modem Europe, ed. Margaret W. Ferguson, Maureen Quilligan, and Nancy J. Vickers (Chicago: University of Chicago Press, 1986); and Michael McCanles, "Love and Power in the Poetry of Sir Thomas Wyatt," MLQ, 29 (1968), I45-160. 
of different methodologies continue to emphasize the potency of the Petrarchan poet, downplaying how his power is subverted, his vessel taken over and driven off course by someone or something stronger than its pilot. Thus, for example, while acutely acknowledging the threats to the sovereignty of the Petrarchan poet, "Gordon Braden nonetheless argues that the tradition focuses instead on his achievements. ${ }^{22}$ Similarly, though feminism has been varied in this and other regards, many studies of the sonnet do emphasize the unassailable hegemony of patriarchy. The image- or mirage - of the omnipotent male poet satisfies many agendas of feminism, at once demonstrating the force of patriarchy in early modern England and exemplifying patterns of domination that indubitably occur in other cultures as well, not least our own. ${ }^{23}$

What case might be made, then, for interpretations like these that deny or downplay any challenges to the poet's power? In analyzing Petrarch and his followers, as in the more specific instance of Poem II 8 , some critics are tempted to protect the conventional wisdom about the power of the poet by discounting Petrarch's lurches between success and failure. One might argue that he succeeds as a poet even if he fails as a lover, a net gain because his main concern is not Laura but the laurel. ${ }^{24}$ But the pun that unites those two goals reminds us that they cannot in fact be divided so easily; Petrarch's problems in achieving speech parallel his difficulties in winning Laura. As Lynn Enterline has demonstrated, he, like Ovid, connects male subjectivity with linguistic problems. ${ }^{25}$ Nor can one dismiss his problems with language as a mere convention, a type of hyperbolic modesty topos: certainly an element of self-consciousness and role-playing informs the poetic speaker's allusions to difficulty in writing, like virtually everything else he says, but Petrarch clearly realizes how soon the mask adheres to the face. In this instance and many others, to dismiss convention as "mere convention" is to misunderstand its workings. Moreover, calling Petrarch's allusions to failure into question in these ways forces us to ask

\footnotetext{
${ }^{22}$ Gordon Braden, "Love and Fame," and "Beyond Frustration: Petrarchan Laurels in the Seventeenth Century," SEL, 26 (1986), 5-23. Also cf. Lauro Martines, who, writing primarily about Italian Petrarchism, finds in that movement an alternative to the frustrated powerlessness its poets experienced in a culture of religious corruption and political and social upheaval (Power and Imagination: City-States in Renaissance Italy [New York: Knopf, 1979], chap. I5).

${ }^{23}$ See, e.g., Margaret Homans, “' 'Syllables of Velvet': Dickinson, Rossetti, and the Rhetorics of Sexuality," Feminist Studies, II (1985), 569-593.

${ }^{24}$ Many critics have made this case; see, e.g., Braden, "Beyond Frustration."

${ }^{25}$ Lynn Enterline, "Embodied Voices: Petrarch Reading (Himself Reading) Ovid," in Desire in the Renaissance: Literature and Psychoanalysis, ed. Valeria Finucci and Regina $M$. Schwartz (Princeton: Princeton University Press, 1994).
} 
to what extent his celebrations of his own poetic success may also be rhetorical ploys that are not completely persuasive. Alternatively, reverting to conceptions of the persona, one might attempt to distinguish the success of the historical personage Petrarch from the failure of the speaker within the sequence-but again the two figures are twins, fraternal though not Siamese or even identical. Above all, they are both subject to the same theological accusations: their indubitable poetic triumphs are always shadowed by the Augustinian condemnation of the imagination. Similar difficulties arise if one tries to dismiss the problems connected with agency: without in any way denying the poetic achievement and historical impact of the Rime sparse, it remains true that those successes are built on a bedrock of writing about failure, a paradox to which we will return several times.

The figure of the pilot who is, paradoxically, victor and victim, captain and captor, is, then, central to Petrarchism - and central as well to why it flourished in England and why it also invited repeated attacks. The seesaw between power and powerlessness which defines the Petrarchan voice was especially attractive to sixteenth-century English poets. Like Laura herself, it was a kind of living magnet that drew them to the perilous islands, shoals, and storms of Petrarchism.

Needless to say, a preoccupation with the elision between power and powerlessness reappears in many cultures: this and the other characteristics that I am identifying as distinctive of the English Renaissance are not unique to it. Yet seldom if ever has that preoccupation been more central than it was in sixteenth-century England. It takes very different forms there, of course, than it does in the Rime sparse; nonetheless, similar issues and tensions arise. It is no accident that The Shepheardes Calendar, the text that inspired so many later Elizabethan poets, balances precariously on that very seesaw between potency and impotence: Spenser celebrates his own debut as a poet and the potentialities of a national literature in a sequence of texts which begins with a broken pipe and ends on a discarded one. Nor is it an accident that The Faerie Queene, as influential in and characteristic of its period as Spenser's pastoral sequence, repeatedly qualifies even the most triumphant moments of its knights with intimations, or worse, of failure: the Red Crosse Knight cannot remain with his beloved, Scudamour does not stay around long enough to enjoy the consummate moment granted him at the end of the I 590 version, and the Blatant Beast survives, sharpening its teeth for the scholarly conferences and conventions that it eagerly foresaw.

The uneasy relationship between success and failure assumes several different but related forms in the texts, in the many senses of that noun, of sixteenth-century England, forms that correspond to the movements of 
Petrarchism itself. At times a triumphant assertion of mastery is followed in rapid succession by its opposite, an acknowledgment of failure; at times success from one vantage point is failure from another; at times one cannot clearly distinguish the two. These patterns stem above all from the coexistence of conflicting status systems, competing values, contesting ideologies, and contrasting communities within the larger culture, a coexistence that by its very nature did not always yield a clearly dominant victor. ${ }^{26}$

These unresolved conflicts are manifest in the conditions of authorship in the period. Defenses of poesy, as Margaret W. Ferguson among many others has demonstrated, are indeed defensive in that culture and its Continental counterparts; ${ }^{27}$ writing love lyrics was particularly suspect in some circles because of the taint of immorality. (Indeed, the fraught status of creative writers in certain of our own English departments, an issue that in itself deserves more attention, might alert us to the dangers of equating poetic achievement and power in the different but not wholly unrelated milieu of sixteenth-century England, as some analyses of Petrarchism do.) $)^{28}$ Petrarch's anxieties on the subject had been reinterpreted and reduced in the two centuries that intervened between the Rime sparse and the flowering of the sonnet vogue in England-reinterpreted, reduced, but not erased. Witness, most obviously, Sidney's defensive posture when protecting his Second Maker from accusations of immorality and impiety; consider his admission that despite the virtues of art it may be abused to "infect the fancy with unworthy objects." 29 By referring to his treatise as an "inkwasting toy" (p. I4I) at a crucial moment, his peroration, he is indulging in a common rhetorical ploy, a modesty topos-but surely he is using that topos so that he can at once express his own doubts and distance himself from them by constructing them as a conventional strategy. And, of course, such doubts were intensified in the instance of the author of love lyrics, who is especially liable to the danger of infecting the fancy. Nor were the standards for evaluating secular poetry consistent. Pleasing one's cohorts at the Inns did not ensure a following at court; writing sonnets did not guarantee admission to the coterie that was circulating Donne's lyrics in manuscript.

\footnotetext{
${ }^{26} \mathrm{On}$ the presence of multiple communities in the Renaissance, compare Jane Tylus, Writing and Vulnerability in the Late Renaissance (Stanford: Stanford University Press, 1993), esp. chap. I. I thank the author for sharing her work with me before publication.

${ }^{27}$ Margaret W. Ferguson, Trials of Desire: Renaissance Defenses of Poetry (New Haven: Yale University Press, 1983).

${ }^{28}$ See, e.g., Braden, "Beyond Frustration."

${ }^{29}$ The citation is to Sir Philip Sidney, An Apology for Poetry or The Defence of Poesy, ed. Geoffrey Shepherd (London: Nelson, 1965), p. 125. Future citations from this edition will appear in my text.
} 
Success and failure were also strange bedfellows in the patronage system in which writers and many others participated, though in this case they were likely to follow each other in rapid succession rather than to coexist. As we have seen, many readers posit a metaphoric link between patronage and the sonnet tradition: sonnets flourished when they did, as Arthur F. Marotti and others have maintained, because their discussions of service to a lady figured the patterns of service at court. ${ }^{30}$ But patronage is most relevant to love poetry because it provides an experience of uncertainty analogous to the Petrarchan seesaw between success and failure. The lament for the "variable, and therefore miserable condition of man" on which Donne opens his Devotions upon Emergent Occasions could aptly gloss not merely the medical and spiritual transformations that he is primarily addressing but also the patronage system that he knew all too well. ${ }^{31} \mathrm{~A}$ patron could prove unable to exercise the influence at court that he and his dependents had anticipated, as did Donne's own unreliable mentor Sir Robert Drury. ${ }^{32}$ Or the royal personage whom the patron was influencing could die; Leonard Tennenhouse has documented the seismic shifts caused by the death of Prince Henry and the consequent unmooring of the many courtiers who had turned to him for patronage. ${ }^{33}$

Both the frequency with which sumptuary laws were promulgated and the frequency with which they were flouted remind us that in sixteenthcentury England, social position and one of its principal components, financial status, were as frangible and variable as was literary success. Their volatility during this period is, of course, a commonplace; witness Spenser's metamorphosis from scholarship boy at his school to landowner in Ireland. But social ranking was further complicated by the coexistence of different systems for assessing it, a cultural pattern that literary critics sometimes overlook. The complex social position enjoyed by widows like Bess of Hardwick reminds us that gender, inherited wealth, recently acquired wealth, and birth all provided different and often conflicting markers of social status. Nor was that status necessarily consistent throughout the country; as I argue in Chapter 4, in assessing systems of ranking, one should not focus only on the court, thus making one little world an everywhere.

\footnotetext{
${ }^{30}$ Arthur F. Marotti, " 'Love is not love': Elizabethan Sonnet Sequences and the Social Order," ELH, 49 (1982), 396-428.

${ }^{31}$ I cite John Donne, Devotions upon Emergent Occasions (Ann Arbor: University of Michigan Press, 1959), p. 7.

${ }^{32}$ On Drury's fortunes, see R. C. Bald, John Donne: A Life (Oxford: Oxford University Press, 1970), esp. p. 238.

${ }^{33}$ Leonard Tennenhouse, "Sir Walter Ralegh and the Literature of Clientage," in Patronage in the Renaissance, ed. Guy Fitch Lytle and Stephen Orgel (Princeton: Princeton University Press, 198I).
} 
Success and failure enjoyed an intimate relationship, then, not only because achievements were fragile but also because perceptions of them could differ so much, with what would be seen as success in one social circle or region coded as failure in another. For this and many other reasons, the Petrarchan pilot who slides back and forth between commanding his ship and being buffeted by unfavorable winds could be an emblem for the position of many writers - and many readers - in Tudor England.

If its uneasy juxtapositions of mastery and impotence help to explain the attraction of Petrarchism in England, two of its central formal patterns, which are often connected to those juxtapositions, do so as well. Both the relationship between the narrative and lyric potentialites of Petrarchism and its predilection for repetition preoccupy, even obsess, its adherents, its detractors, and the many writers who cannot be fairly classified through either label. And both of these formal dynamics correspond to cultural dynamics, thus further explaining the position of Petrarchism in English culture.

The poems of both Petrarch and his followers compromise the connections between narrative and masculinity, as well as narrative and masculine power. The relationship between narrative and lyric in Petrarch's Rime sparse is significant in part, then, because this arena is one of many in which that slippage between mastery and impotence is staged. But his poems can also help to illuminate broader theoretical questions about those two modes. What happens when theories of narrativity, which have most frequently been developed through and applied to nineteenth- and twentiethcentury novels, are played against medieval or Renaissance lyrics? What happens to conventional critical assumptions about the gendering of narrative when they are played against the storytelling propensities of that master and slave of gender, Petrarch?

Lyric has traditionally been seen as an unmediated expression of the subjective and of subjectivity itself. It is frequently associated, too, with the absence of a specific time and place, characteristics that help to explain its use of what George T. Wright describes as the "lyric present." ${ }^{34}$ Many critics would agree that narrative, in contrast, is generally rooted in a specific time and place. Narrative theorists ranging from Peter Brooks to $\mathrm{Te}-$

${ }^{34}$ George T. Wright, "The Lyric Present: Simple Present Verbs in English Poems," PMLA, 89 (1974), 563-579. 
resa de Lauretis have connected narrativity with male desire, ${ }^{35}$ for this and other reasons, it is often seen as gendered masculine, whereas lyric is feminine, even though male poets predominate among its writers. ${ }^{36}$ Such distinctions have, however, been challenged in many quarters and from many perspectives. For example, several students of lyric remind us that the apparent lack of mediation may itself be a rhetorical ploy. ${ }^{37}$ Sharon Cameron's important study of that mode, incisive despite the problems created by treating Dickinson as its normative case, suggests that the concern with death that so often characterizes lyric directs attention towards temporality. ${ }^{38}$ Notwithstanding such disputes, the familiar descriptions of lyric as ahistorical and subjective remain influential. To carve a working definition from among these controversial interpretations of that mode, I will focus on two frequently accepted characteristics of lyric, atemporality and subjectivity, though I attempt as well to problematize those and other categorizations.

Not the least of the many ways Petrarch distinguishes himself from Dante is his approach to the relationship between narrative and lyric (indeed, as Roland Greene rightly notes, Petrarch's principal transformation of his models centers on a question connected to that relationship, temporality)..$^{39}$ Whereas the Vita Nuova links its poems with narrative commentary, the Rime sparse establishes a more covert and conflicted relationship between the two modes. This much is clear, but critics part company on how to describe Petrarch's approach to narrative and lyric. For example, in one of the most powerful treatments of the subject, Teodolinda Barolini argues that Petrarch manipulates the narrative elements in the sequence to defuse and conquer time..$^{40}$ Aldo Scaglione emphasizes open notions of form and

\footnotetext{
${ }^{35}$ See Peter Brooks, Reading for the Plot: Design and Intention in Narrative (New York: Vintage Books, 1985), esp. chaps. 2, 4; and Teresa de Lauretis, Alice Doesn't: Feminism, Semiotics, Cinema (Bloomington: Indiana University Press, 1984), chaps. I, 5 .

${ }^{36}$ For a refutation of that conventional wisdom from a perspective different from my own, see Susan Stanford Friedman, "Lyric Subversion of Narrative in Women's Writing: Virginia Woolf and the Tyranny of Plot," in Reading Narrative: Form, Ethics, Ideology, ed. James Phelan (Columbus: Ohio State University Press, 1989).

${ }^{37}$ On revisionist readings of lyric, see Sharon Cameron, Lyric Time: Dickinson and the Limits of Genre (Baltimore: Johns Hopkins University Press, 1979); Jonathan Culler, "Changes in the Study of the Lyric," in Lyric Poetry: Beyond New Criticism, ed. Chaviva Hošek and Patricia Parker (Ithaca: Cornell University Press, 1985); and Patricia Parker, introduction to Lyric Poetry.

${ }^{38}$ Cameron, Lyric Time, esp. chap. 3.

${ }^{39}$ Roland Greene, Post-Petrarchism, p. 22.

${ }^{40}$ Teodolinda Barolini, "The Making of a Lyric Sequence: Time and Narrative in Petrarch's Rerum vulgarium fragmenta," MLN, I04 (1989), I-38.
} 
the presence of an order that is not based on logic. ${ }^{41}$ In an influential essay, Thomas P. Roche Jr. identifies calendrical patterns in the sequence, adducing them to demonstrate that secular desires are played against spiritual verities; ${ }^{42}$ such patterns, like the many other types of shape critics have (with widely varying degrees of persuasiveness) located in the sonnet tradition, complicate analyses of temporality and narrativity.

Poem 142 exemplifies the complex relationship between narrative and lyric in Petrarch's sequence:

A la dolce ombra de le belle frondi
corsi fuggendo un dispietato lume

Però più fermo ogni or di tempo in tempo, seguendo ove chiamar m'udia dal cielo

Tanto mi piacque prima il dolce lume ch' i' passai con diletto assai gran poggi per poter appressar gli amati rami; ora la vita breve e 'l loco e 'l tempo mostranmi altro sentier di gire al cielo et di far frutto, non pur fior et frondi.

Altr'amor, altre frondi, et altro lume, altro salir al ciel per altri poggi cerco (che n'è ben tempo), et altri rami.

(I42.I-2, 19-20, 31-39; To the sweet shade of those beautiful leaves I ran, fleeing a pitiless light.... Therefore, more and more firm from season to season, following where I heard myself called from Heaven.... So pleasing to me at first was that sweet light that joyfully I traversed great hills in order to approach the beloved branches. Now the shortness of life and the place and the season show me another pathway to go to Heaven and bear fruit, not merely flowers and leaves. Another love, other leaves, and another light, another climbing to Heaven by other hills I seek [for it is indeed time] and other branches.)

${ }^{41}$ Aldo Scaglione, "La struttura del Canzoniere e il metodo di composizione del Petrarca," Lettere Italiane, 27 (1975), I 29-139.

${ }^{42}$ Thomas P. Roche Jr., "The Calendrical Structure of Petrarch's Canzoniere," SP, 7I (1974), I $52-172$. 
In one sense the whole poem pivots on the concept of temporal change so central to lyric: then the speaker sought Laura, now he seeks heaven. This emphasis on diachronic shifts is underscored as well by descriptions of changes in the material world (now, lines twenty-five and twenty-six declare, woods, rocks, and so on are conquered by time) and by the repetition of altre (other) no fewer than three times in line thirty-seven. As these instances would suggest, narrativity both describes and enables the movement from earthly to heavenly love. It is precisely the ability to contrast then and now that permits him to contrast here, the world of secular love that at its best encourages him to seek the divine, and there, the world of heavenly love. And it is the ability to tell a story that synecdochically represents the possibility of spiritual change and growth.

And yet not so. Or at least, as is so often the case with Petrarch, and yet not quite so. The poem seems to contradict itself at several points, as when Petrarch follows the observation that the laurel is the tree most favored in heaven with the statement that it defended him against the heavens (12-13). The repeated rhymes of the sestina figure the underlying question that destabilizes the patterns I have been describing: Is change really possible? Perhaps, as the identity of "l'aura" and "Laura" would suggest, the speaker cannot truly distinguish the light that comes from heaven and that which comes from Laura. Perhaps, as his sometimes contradictory commentary would suggest, the poem attempts to establish and inhabit a world of linearity and narrativity but instead is pulled back into the lyric stasis suggested by its repetitive rhymes. In a sense the slippage into lyric here culminates in other texts whose repeated reliance on apostrophe is the syntactical analogue to the breakdown of narrative: "O passi sparsi, o pensier vaghi et pronti, / o tenace memoria, o fero ardore" (I6I.I-2; "O scattered steps, $\mathrm{O}$ yeaming, ready thoughts, $\mathrm{O}$ tenacious memory, $\mathrm{O}$ savage ardor").

Similarly, many poems in Petrarch's sequence could be classified as a vision or that sibling of the vision, the dream, and both of those modes inherently challenge distinctions between narrative and lyric. ${ }^{43}$ Thus the vision often involves narrating a story ("One day as I walked by the river I saw") and an insistently teleological story culminating in some apocalyptic change at that ("and at the end he arose from the dead" or "and it was just a dream"). But visions, like lyric, are by definition also intensely subjective, and they are often though not inevitably located in an indetermi-

${ }^{43}$ One of the best studies of narrative and lyric, Jay Clayton's Romantic Vision and the Novel (Cambridge: Cambridge University Press, 1987), emphasizes the complex overlappings of the modes but primarily links the visionary to lyric. 
nate landscape rather than a specific time and place. Moreover, visions often involve repetition, which itself frequently blurs the line between narrative and lyric.

Petrarch's anniversary poems demonstrate how the visionary mode encourages complex combinations of narrative and lyric. In one sense these lyrics are typically narrative, involving as they do not one but two stories: the original tale of seeing Laura and the tale of recalling that moment. In addition, they firmly foreground time and place by emphasizing the number of years since the first sight of Laura and referring specifically to the locales in which she has been sighted. If, as Tzvetan Todorov has claimed, narrative is based on the tension between difference and resemblance, ${ }^{44}$ these poems certainly focus on that tension by reminding us that the passage of time, the graying of the narrator's hair, separates this vision from the original one - and yet that original one is relived in the course of the poem. Petrarch's anniversary poems are, however, also intensely lyric in their emphasis on the static and subjective experience they evoke.

Bearing in mind, then, the complexity of labeling the modes of the Canzoniere, how does that sequence engage with the gendering of narrative and lyric, one of the Petrarchan legacies that was to prove of especial significance to English poets, and with related issues of empowerment? Here narrative is male, both in the obvious sense that Petrarch himself shapes stories about his experience and in so doing shapes that experience and in the less obvious but no less significant sense that he tells stories about the future as well. If he is the victim Actaeon, he is also Apollo, god of prophecy. Indeed, the Coronation Ode emphasizes the poet's role as seer. ${ }^{45}$ Such narratives about the future were to figure prominently in the work of many of his successors, notably Shakespeare. Narrative, too, is associated very specifically with what is potentially the principal triumph of the sequence: the movement towards God. For that movement depends on distinguishing a past of loving only Laura, a present of moving towards God, and a future of achieving spiritual peace. Witness the emphasis on temporality in Sonnet I. And yet, as that poem and many others remind us, the movement towards God — and the narrativity that expresses it - are at the very least destabilized by the pull back towards Laura.

Indeed, Petrarchan narrative is often connected not with the empow-

\footnotetext{
${ }^{44}$ Tzvetan Todorov, The Poetics of Prose, trans. Richard Howard (Ithaca: Comell University Press, 1977), p. 233.

${ }^{45}$ Compare Aldo S. Bernardo, "Petrarch and the Art of Literature," in Petrarch to Pirandello: Studies in Italian Literature in Honour of Beatrice Corrigan, ed. Julius A. Molinaro (Toronto: University of Toronto Press, 1973), 27-30.
} 
errnent of the male speaker and of the masculine in general but with their loss of power. Though in one respect Petrarch shapes narratives, in another respect narrative is associated with what happens to him against his will: the discontinuous storytelling in Canzone 23, among others, figures the sense in which his metamorphoses, like the changes that constitute narrative, are outside his control. With due respect to Barolini, although Petrarch the poet obviously crafts skilled narratives, the poetic speaker with whom he is so intimately associated is more often a victim of narrativity than its manipulator ${ }^{46}$ One of the many senses in which Laura is linked to the lyric world of stasis and Petrarch to the narrative world of linear change is that, despite her death, she is frequently described as evergreen while, as he repeatedly reminds us, he ages and grows gray. Sometimes the ultimate loss of power and control, the disappearance of the vision of Laura, is presented as a fall from lyric contemplation to narrative movement. Witness the sonnet in which that loss involves a literal fall: "quand" io caddi ne l'acqua et ella sparve" (190.14; "when I fell into the water, and she disappeared").

If narrative is sometimes gendered male, then, it is not necessarily or invariably associated with male power. The customary association between storytelling and the quest of male desire is compromised as well. Inasmuch as that desire takes the form of a movement towards God, it is certainly expressed through narrative; indeed, in the Rime sparse the movement from lyric to narrative is often a shift from entrapment in earthly love to a progress, however impeded, however distrusted, towards the spiritual. But loving Laura is a very different matter, one expressed not as a narrative quest but as the inability to pursue that or any other quest. Loving Laura is the state that, as we observed, is memorably encapsulated at the end of Poem I 8: "né per mille rivolte ancor son mosso" " "nor for a thousand turnings about have I yet moved"). Loving Laura is a sestina of apparent shifts that are really just repetitions.

This compromising of the connection between narrative and male sexual desire is not, however, sui generis. Conventional definitions of narrative suffer from the literary equivalent of that bête noire of contemporary criticism, essentialism: they do not allow sufficiently for the variations engendered by different cultures and different historical periods. In the Middle Ages, I would suggest, writers besides Petrarch were more likely to associate desire with lyric than with narrative. As analyzed by Aristotle and Aquinas, concupiscence, in contrast to irascibility, may be seen as passive and fem-

${ }^{46}$ Barolini, "The Making of a Lyric Sequence." 
inine; it is no accident that it is often connected with Venus. ${ }^{47}$ Moreover, affective piety, the highly influential religious movement that emphasizes emotional rather than speculative approaches to religion, frequently stresses a passive receptivity rather than an active search for God. ${ }^{48}$ To be sure, the commonplace metaphor of spirituality as a journey survives in these writers, but often they describe the quest for union with God in more passive terms. Thus Bernard of Clairvaux stresses both the difficulty and the importance of surrendering one's will to God; in his commentary on the Song of Songs, the Bride, having strewn the chamber of her heart with flowers, waits there for God, and elsewhere he describes her as being led into the chamber. ${ }^{49}$ Similarly, St. Bonaventure stresses that we must be "led in the path of God." ${ }^{0}$ As Caroline Walker Bynum points out, such passages demonstrate that medieval writers often see spiritual experience as an acceptance of a position otherwise gendered female. ${ }^{51}$ Paradoxically, much as Pandarus's condemnations of Troilus's effeminate behavior establish and buttress a conventionally masculine norm in Chaucer's text, ${ }^{52}$ so this medieval construction of desire as passive and effeminizing might perhaps be seen as preserving and even strengthening an alternative model of male desire. By loving in a feminine way, this argument would run, Troilus draws attention to the masculine alternative, the connection of narrative and male action. But, as many studies of androgyny have indicated, when men are repeatedly portrayed in relation to a state normally gendered female or vice versa, binary gender categories may be challenged as well as, or rather than, asserted. ${ }^{53}$ In short, many medieval texts serve to confound, not confirm or contradict, the connections between narrative and male desire.

Hence Petrarch's approach to narrative and lyric invites us to pose

${ }^{47}$ On Christian theories of love and desire, see esp. Anders Nygren, Agape and Eros, trans. Philip S. Watson, rev. ed. (Philadelphia: Westminster, I953).

${ }^{48}$ For a useful summary of affective devotion, see Douglas Gray, Themes and Images in the Medieval English Religious Lyric (London: Routledge and Kegan Paul, 1972), chap. I.

${ }^{49}$ Bernard of Clairvaux, Selected Works, trans. G. R. Evans (New York: Paulist, 1987), esp. pp. I79-I 81 .

${ }^{50}$ Bonaventure, The Soul's Joumey into God, The Tree of Life, The Life of St. Francis, trans. and ed. Ewert Cousins (New York: Paulist, 1978), p. 60.

${ }^{51}$ Caroline Walker Bynum, “ ' . . . And Woman His Humanity': Female Imagery in the Religious Writing of the Later Middle Ages," in Gender and Religion: On the Complexity of Symbols, ed. Caroline Walker Bynum, Stevan Harrell, and Paula Richman (Boston: Beacon, 1986), esp. p. 258.

${ }^{52}$ I am grateful to Donald W. Rowe for suggesting the Chaucerian parallel to me.

${ }^{53}$ Androgyny has been widely discussed by feminisw and other students of gender during the I980s and I990s. For a particularly influential treatment, see Phyllis Rackin, "Androgyny, Mimesis, and the Marriage of the Boy Heroine on the English Renaissance Stage," PMLA, 102 (1987), 29-4I. 
broader revisionist questions about those modes and their role in English Petrarchism and anti-Petrarchism. To what extent can critics accept the conventional wisdom on masculine empowerment via narrative? Is the relationship between the two modes often, as in the instance of Petrarch himself, an unresolved struggle? And does that conflict between narrative and lyric stage a struggle to define male subjectivity and assert male power, a process that is complicated both because gender categories erode and overlap and because narrative does not in fact necessarily establish the power of its narrator? In refining and redefining the connections between narrative and lyric which they encountered in Petrarch and his continental imitators, English poets map subjectivity and its discontents.

\section{V}

Repetition, we have just observed, may erode the line between narrative and lyric in much the same way and for many of the same reasons that the refrain erodes the line between the closural and the anticlosural; one of the most deconstructive of tropes, it both announces and erases temporality. ${ }^{54}$ But repetition is also central in many other ways in Petrarch's sequence, and its role has hardly gone unnoticed. Thomas M. Greene, for example, writes about Petrarch's "iterative present" 55 Guiseppe Mazzotta trenchantly observes that the Rime sparse appears to represent "a coherent unity and totality, but the unity always appears to be made of contiguous, adjacent parts that steadily repeat themselves, even while they aspire to mark new imaginative departures. ${ }^{56}$

As these commentaries would suggest, repetition assumes many forms within the Rime sparse. Most obviously, it is apparent in the stanzaic patterns of the Petrarchan sonnet, like those of its Shakespearean counterpart. The poet may return to and re-create an action or an incident or an image, as he does in the anniversary poems. Or he may repeat an action continuously, as he does in many of the poems that describe his wandering movements. Frequently that form of repetition generates the paradox of movement without change- "l'aura mi volve et son pur quel ch' i' m'era" (I I2.4; "the breeze turns me about, and I am still just what I was"). And while I have argued that repetition often threatens narrative, some of the passages

${ }^{54}$ For a related but different argument, see Clayton, Romantic Vision, esp. pp. I08-I I5; he argues that repetition is central to both narrative and lyric.

${ }^{55}$ Thomas M. Greene, The Light in Troy, esp. pp. II 8-120.

${ }^{56}$ Guiseppe Mazzotta, "Petrarch's Song 126," in Textual Analysis: Some Readers Reading, ed. Mary Ann Caws (New York: Modern Language Association, 1986), p. 129. 
in question could be explained by Brooks's emphasis on the centrality of repetition to narrative..$^{57}$

But perhaps the most revealing instance is a section of Canzone 23, the altered rendition of the Actaeon myth. Although Nancy J. Vickers's influential study of the passage adduces it subtly to analyze Petrarch's fear of dismemberment, especially castration, that argument neglects the fact that dismemberment is precisely what does not occur in these lines. ${ }^{58}$ To be sure, when Actaeon is evoked elsewhere in the sequence, he is, like his stepbrother Orpheus, torn apart. But the passage at hand, the locus classicus for Petrarch's rendition of the myth, in fact culminates not in decisive destruction but in the repetition of an action:
ch' i' senti' trarmi de la propria imago
et in un cervo solitario et vago
di selva in selva ratto mi trasformo,
et ancor de' miei can fuggo lo stormo.

(23.157-I60; for I felt myself drawn from my own image and into a solitary wandering stag from wood to wood quickly I am transformed and still I flee the belling of my hounds.)

The poet's experience repeats that of Actaeon and of the lady; and that experience is presented as one form of repetition, the inability to escape from a continuing action.

Such passages help us to understand why repetition is so important within the Rime sparse and why it proved so significant a legacy to Petrarch's followers and detractors. Recurrence is associated with sin in several ways. Petrarch repeats the Fall of Adam, as Sara Sturm-Maddox has shown us, ${ }^{59}$ and what is more, he repeats his repetition of it in each anniversary poem. Similarly, when Petrarch's alter ego Orpheus looks back, he represents man's tendency to return to sin, according to some medieval and Renaissance commentators. ${ }^{60}$ But Petrarchan repetition is also the trope that writes and is written by erotic desire. For repetition represents the way that impulse is never finally satisfied and hence never finally controlled-

${ }^{57}$ Brooks, Reading for the Plot, esp. chap. 4.

${ }^{58}$ Nancy J. Vickers, "Diana Described: Scattered Woman and Scattered Rhyme," Critical Inquiry, 8 (198I), 265-279.

${ }^{59}$ Sara Sturm-Maddox, "Petrarch's Serpent in the Grass: The Fall as Subtext in the Rime sparse," Joumal of Medieval and Renaissance Studies, 13 (1983), 2 13-226.

${ }^{60}$ See, e.g., the commentary on Boethius's version of the myth in John Block Friedman, Orpheus in the Middle Ages, pp. 89-96. 
"Had, having, and in quest to have, extreme" (Shakespeare, Sonnet I29, 10). ${ }^{61}$ Its obsessive, uncontrolled reversions exemplify the loss of agency that we have traced from other perspectives. And its erosion of the boundaries between narrative and lyric, between past and present, recalls yet again the erosion of gender distinctions which characterizes Petrarchism.

Petrarchan repetition also often represents a drive that is exemplified by but not confined to desire: the urge towards reenactment in the psychoanalytic sense, that is, repeating an action to assert mastery. In Freudian terms, reenactment is the attempt to turn failure and powerlessness into success and power ${ }^{62}$-in other words, it is the attempt to arrest the seesaw between failure and success which is at the heart of Petrarchism, which helps to explain why repetition is itself at the heart of the sequence. Lacan, however, glosses this form of reenactment more accurately than Freud, for Petrarch's is a reenactment that, like so much in the sequence, is doomed to failure. Thus although repetition that attempts to assert mastery, to win the game of fort-da once and for all, seems the opposite of repetition that relives the Fall and returns to sin, in reality the two are closely allied, for Petrarch's version of reenactment merely repeats the problems it attempts to resolve. Indeed, throughout the sequence, repetition is associated with entrapment. Therefore, as we have already seen, the repetitions of lyric may represent Petrarch's inability to escape from Laura-or rather from the images of her, images that Augustine would consider the dangerous detritus of the imagination.

An attraction to repetitive literary structures and the formal and other cultural agendas they embody is not, of course, unique to early modern England; indeed, many literary theorists have even seen repetition as a central structuring force in virtually all literature. ${ }^{63}$ The English Renaissance, however, manifests a particularly intense attraction to this mode. Three of its most popular literary types-the sonnet, romance, and pastoral-involve multiple forms of it. The Faerie Queene may at first seem an

${ }^{61}$ Stephen Booth, ed., Shakespeare's Sonnets (New Haven: Yale University Press, 1977).

${ }^{62}$ On reenactment and fort-da, see esp. chap. 2 of Sigmund Freud, Beyond the Pleasure Principle, The Standard Edition of the Complete Psychological Works of Sigmund Freud, trans. James Strachey et al., vol. I 8 (London: Hogarth Press and Institute of Psycho-analysis, 1955). For Lacan's more pessimistic reinterpretation, see esp. "The Function and Field of Speech and Language in Psychoanalysis," in Ecrits: $A$ Selection, trans. Alan Sheridan (New York: Norton, 1977), pp. I02-104. After completing this book, I found that Gary Waller also notes connections between Petrarchism and fort-da, though he applies the analogy differently from the way I do (The Sidney Family Romance: Mary Wroth, William Herbert, and the Early Modem Construction of Gender [Detroit: Wayne State University Press, 1993], p. I49); I regret that his volume appeared after my own book was virtually finished.

${ }^{63}$ See, e.g., Todorov, The Poetics of Prose, esp. pp. II6-I I7. 
exception to this fascination: epic, after all, distinguishes itself from romance through its linear thrust and intense closural drive. But this is an exception that proves the rule, for Spenser's poem characteristically eschews closure in favor of repetition. His Blatant Beast, the poem implies, will be repeatedly chased and will repeatedly escape.

One of the deepest fantasies in Tudor and Stuart England, I suggest, is uncontrolled repetition emanating from a single case, a single error-a metaphoric rendition of contagion. Revenge plays are so popular in both Tudor and Stuart England in part because they anatomize precisely this pattern. Compare too Arden of Faversham, which presents the repetitiveness associated with an attempted murder, or Spenser's reduplicated evil triplets, Sansloy, Sansjoy, and Sansfoy. Indeed, it is no accident that two of the telling passages in the literature of that culture-Spenser's description of Error's brood and Milton's case study of Sin's obstetrical records-involve a similar version of the fear that a single transgression will repeat and multiply, in these instances multiply in the most literal sense. ${ }^{64}$ As these texts remind us, the fear that one error will breed another recalls original sin, ${ }^{65}$ and it is telling that Thomas $\mathrm{M}$. Greene's reading of repetition in the Rime sparse alludes to a "fall into iteration." 66

Texts of the English Renaissance respond to these anxieties about uncontrollable and unstoppable reduplication in three principal ways. First, the culture devises myths for and about itself which incorporate potentially threatening repetition into overarching patterns of linearity and teleology. Witness above all the notion of Trojan descent, which includes but subsumes repetition. Witness too the central model for a poetic mission, the Virgilian wheel, which acknowledges repetition in the emphasis on replicating Virgil's career and in the image of circularity itself, yet plots that repetition in terms of a progressive, linear growth from pastoral to georgic to epic. Second, many apparently disparate practices in both Tudor and Stuart England may in fact be seen as attempts to redefine repetition as control and order. The refrain uses repetition to suggest a reassuring aesthetic order; typology, like liturgy, uses repetition to suggest a reassuring spiritual order. As those instances indicate, one way of redefining recur-

${ }^{64}$ I am indebted to Linda Gregerson for fruitful discussions of these episodes.

${ }^{65}$ Compare Thomas $P$. Roche Jr.'s observation that in Barnes's poetry, like that of Spenser, verbal repetition is connected with sin (Petrarch and the English Sonnet Sequences [New York: AMS Press, 1989], p. 173). For a different but not incompatible argument about religion and repetition, see Kristen Poole, "Saints Alive! Falstaff, Martin Marprelate, and the Staging of Puritanism," SQ, 46 (1995), 47-75. She demonstrates that Puritans were seen in tenns of grotesque proliferation.

${ }^{66}$ Thomas M. Greene, The Light in Troy, p. 126. 
rence is to recast it as repetition-with-a-difference ${ }^{67}$ - which is, of course, the dynamic behind the psychoanalytic process of reenactment-as writers in the African-American tradition were to assert when they developed their practices of signifying. ${ }^{68}$

Finally, Petrarchism itself serves to negotiate cultural attitudes towards repetition. Both Petrarchism and its counterdiscourses attract writers and readers in Renaissance England in no small measure because they are, above virtually all other traditions, the discourses of repetition. The subjectivity of the Petrarchan lover in England, like that of his Continental counterparts, is mapped by means of several coordinates of repetition: he repeats a conventional literary language that is itself loaded with tropes of repetition, he perpetually reenacts previous attempts to win the lady's favor in the hope that this time the game of fort-da can cease, and he sometimes constructs his relationship to his counterparts in the tradition as a version of repetition-with-a-difference. The counterdiscourses of Petrarchism, as we will observe throughout this study, attempt both to escape and to exemplify Petrarchan repetition; often they provide a release from Petrarchan problematics which is at best partial, on the one hand asserting types of agency denied the Petrarchan poet while on the other rehearsing some patterns from that discourse.

\section{I}

Petrarch's own poetry, then, helps us to understand how and why repetition attracted his followers. Petrarch himself does not, however, provide a clear blueprint for later writers' approach to the Petrarchan mistress and many of the questions about both male and female gender categories that she poses: constructions of both gender and the Petrarchan lady vary significantly from culture to culture, sequence to sequence, and even of course from poem to poem within a given cycle. But reading the Rime sparse does serve to indicate some of the problems in these areas which were to shape English Petrarchism and its counterdiscourses.

Even more to the point, reading Petrarch's text warns us against underestimating the significance of gender in explaining the popularity of those

${ }^{67}$ Sandra $\mathrm{L}$. Bermann also alludes to repetition-with-a-difference in her analyses of $\mathrm{Pe}$ trarchism, but she focuses on asymmetical repetitions and the tensions they create (The Sonnet over Time: $A$ Study in the Sonnets of Petrarch, Shakespeare, and Baudelaire [Chapel Hill: University of North Carolina Press, 1988], pp. 2- 5 ).

${ }^{68}$ On this influential concept, see Henry Louis Gates Jr., The Signifying Monkey: A Theory of African-American Literary Criticism (New York: Oxford University Press, 1988). 
traditions. Sparked by Marotti's influential observation that "love is not love" and by related articles by Ann Rosalind Jones and Peter Stallybrass among others, ${ }^{69}$ many critics have found the ostensible subject of these poems a guise for their true concerns, arguing in effect that the erasure of the female is reduplicated in that not only is the mistress silenced within the poems but their putative romantic plot is essentially silenced as well by their actual agenda. This corrective, though initially valuable, has been taken too far. Although these poems address a range of cultural issues, including ambition, Laura is far more than a decoy and gender far more than the vehicle of a political metaphor. Indeed, Laura's role involves confusions of gender and reinterpretations of speech and silence which are central to the popularity of Petrarchism and its counterdiscourses in Elizabethan-and Elizabeth's-England.

Once again Petrarch's poetry resists generalizations, for Laura is portrayed in varied and contradictory ways. Gentle and stonelike, loving and cruel, she both generates and exemplifies the oxymoron. Yet despite, or sometimes because of, these contradictions, some general patterns emerge. In particular, the poetry seesaws between the denials of her subjectivity which one might anticipate and assertions that she possesses not only subjectivity but considerable agency too.

To begin with, Laura is repeatedly aestheticized. Her tears are described as "belle" (I 58.13; "lovely") and her braids compared not just to gold but also to polished gold (196.8). In such passages, Petrarch certainly objectifies her much as Gilbert Osmond tries to objectify the wife he adds to his collections; but, as we will see, aestheticization serves different functions elsewhere in the sequence.

Petrarch, that Pygmalion who celebrates her, variously erases and redesigns her body as well, describing her gold braids and eyes with particular intensity. But he, unlike many of his French followers, refers only rarely to other, more erotic body parts; though critics talk about Petrarch's blazons, what he in fact generally provides are truncated blazons that dwell on just a few areas of her body. As Peter Hainsworth reminds us, on one of the unusual occasions when he does refer to her breast, he chooses a Latinate term. ${ }^{70}$ And even the bodily parts to which Petrarch does allude are as disembodied as the smile of the Cheshire cat, for descriptions of Laura repeatedly slide away from materiality. This is to some extent true of other descriptions in the sequence as well-Hainsworth notes the telling

${ }^{69}$ Ann Rosalind Jones and Peter Stallybrass, "The Politics of Astrophil and Stella," SEL, 24 (1984), 53-68.

${ }^{70}$ Peter Hainsworth, Petrarch the Poet, p. I 21. 
lack of shapes and of precise shades of color throughout the Rime sparse ${ }^{71}$ -but it is especially marked in the case of Laura herself. Her very body is evoked through absence and emptiness, through a footprint rather than a foot.

What prevents us, then, from simply endorsing the many readings that emphasize the erasure of Laura herself and the construction of the female as lack in more than one sense of that word? In many of the texts of Petrarch, she is erased to the extent and in the ways the male poet is himself: the construction of gendered categories is rooted in their deconstruction. For, as we have already observed, Petrarch and Laura, like Watson and his Echo, are repeatedly elided in a text that blurs boundaries in so many other ways as well. The fusion of subject and object, Joel Fineman reminds us throughout Shakespeare's Perjured Eye, is common in love poetry, ${ }^{72}$ but in few sequences is it effected as frequently as in this one. Most obviously, of course, Petrarch's emblem, the laurel, is hers as well. If the text alludes to her veil, he at times sports one too (see, for example, Poem II9, in which a reference to her veil is succeeded fifteen lines later by a reference to his). If she is a stone, so too is he, and if she sings, he does so as well. This confounding of subject and object, male and female, complicates gender categories in ways that English poets were to pursue.

It is above all in the treatment of Laura's voice that the complex process through which she is variously denied and granted subjectivity and agency is effected. Two revealing passages demonstrate, however, the problems of analyzing her speech. In one, words are dismissingly labeled "queste dolci tue fallaci ciance" (359.4I; "these sweet deceptive chatterings of yours"); in the other, the failure to obey the injunction " $\mathrm{Di}$ ciò non far parola" " (23.74; " 'Make no word of this'") leads to punishment. Textbook examples, then, of the cultural imperative to silence woman metaphorically by devaluing her speech or to silence her literally by forbidding it-except that these instances refer to Petrarch's speech. Male speech is as multivalent in this sequence as the biographies of two of its prime representatives, Battus and Orpheus, would suggest. My main point, however, is not that the ambiguity of gender categories which marks this sequence creates an elision between male and female speech together with so many other elisions; that happens occasionally, but by and large the two forms of language are more clearly distinguished in the sequence than are other characteristics

\footnotetext{
${ }^{71}$ Hainsworth, Petrarch the Poet, p. 194.

72Joel Fineman, Shakespeare's Perjured Eye: The Invention of Poetic Subjectivity in the Sonnets (Berkeley: University of California Press, 1986). Many other critics have commented on that fusion in Petrarchism and elsewhere; see, e.g., Braden, "Beyond Frustration," p. 9.
} 
of Petrarch and Laura. More to our purposes now, because Petrarch constructs his own speech in very much the terms his readers might anticipate for Laura's, it is not surprising to find that the sequence as a whole challenges many assumptions about the relationship among speech, power, and gender.

Another medieval text (if indeed Petrarch should be classified among medieval writers) may also prepare us for those challengesby complicating the resonances of silence. In the Corpus Christi play the raucous noise of Christ's tormentors contrasts with his silence, which seems, like the final silence of Shakespeare's Iago and Melville's Babo, to represent a form of power. ${ }^{73}$ Indeed, far older precedents testify to the value of silence: Egyptian discussions of rhetoric stress its efficacy. ${ }^{74}$ And if Christ's refusal of speech can be decoded positively, under many circumstances the possession of language was coded negatively as well. To Petrarch and his contemporaries, language in its current form was a sign of the Fall as well as a tribute to the reason that separates man from beast, and, as several commentators have pointed out, Saussure could have taught them little they did not already know about the separation between signifier and signified. ${ }^{75}$ Analogues like these wam us again against merely reading speech positively and silence negatively or associating the first with agency and the second with its absence.

Allusions to Laura's speech are as frequent as they are paradoxical. Dante had celebrated the "salute" or greeting of Beatrice, comparing her speech to that of God. But Laura's speech is even more central to the sequence. First, as I already suggested, it is one of the characteristics in the litany by which she is praised: in the Rime sparse and in the Secretum as well, Petrarch evokes Laura by referring to her eyes, her voice, and her movements, a list ritualized enough to recall descriptions of a locus amoenus. Moreover,

${ }^{73}$ Compare V. A. Kolve, The Play Called Corpus Christi (Stanford: Stanford University Press, 1966), pp. 182-186. The power of silence is also discussed in Mimi Still Dixon's unpublished paper, "Seeing and Saying in The Winter's Tale," which relates Hermione's silence to her martyrdom, and in Christina Luckyj, " 'A Moving Rhetorike': Women's Silence and Renaissance Texts," Renaissance Drama, 24 (1993), 33-56. I thank these authors for making their work available to me.

${ }^{74}$ Michael V. Fox, "Ancient Egyptian Rhetoric," Rhetorica, I (1983), I2-I4.

${ }^{75} \mathrm{Medieval}$ attitudes towards language have, of course, been widely discussed. For instances of several different approaches, see, e.g., R. Howard Bloch, Etymologies and Genealogies: A Literary Anthropology of the French Middle Ages (Chicago: University of Chicago Press, 1983); G. L. Bursill-Hall, Speculative Grammars of the Middle Ages: The Doctrine of "Partes Orationis" of the Modistae (The Hague: Mouton, 1971); Marcia L. Colish, The Mirror of Language: $A$ Study in the Medieval Theory of Knowledge, rev. ed. (Lincoln: University of Nebraska Press, 1983); and R. H. Robins, Ancient and Medieval Grammatical Theory in Europe with Particular Reference to Modern Linguistic Doctrine (London: Bell and Sons, 195I). 
he repeatedly emphasizes how deeply her words have affected him. Yet Laura is granted direct discourse relatively infrequently, and almost all the instances occur in the "in morte" sonnets.

Several of the paradoxes associated with Laura's speech and with speech in general in the Rime sparse are resolved if one distinguishes patterns in the "in vita" sonnets from those in their "in morte" counterparts. Although the precise point of delineation between those two groups is the product of scholarly convention more than authorial intention, the fact remains that the second group of poems does differ from the first in a range of ways; for example, as Oscar Büdel demonstrates, Laura is, paradoxically, further removed from Petrarch when she is presented as alive than she is after her death. ${ }^{76}$

The nexus of gender, silence, and impotence is variable and unstable in the "in vita" lyrics. In some sonnets Laura is surely silenced in every sense of that complex term. In others, as we have seen, lacking her own voice, she merely repeats the words Love has taught her. So too, however, does Petrarch on other occasions, and Dante before him as well, for in the twenty-fourth chapter of the Vita Nuova, its author describes himself as leaming what Love dictated to him. Indeed, might not the fear that male speech is itself ventriloquized, whether by a patron, a previous author, or a force like Cupid, attract certain Tudor and Stuart writers to the myth of Echo on which this book opened? That story, like so many other narratives in the mythologies of gender, deflects behavior men fear within themselves onto a woman.

Moreover, in other instances Petrarch's "in vita" poems more overtly challenge the linkage of literal silence (or its analogue, dictated speech), powerlessness, and gender. For Laura does speak frequently, and although her speech is not equivalent to male speech, neither is it denigrated as clearly inferior. The repeated association between her words, her eyes, and her movements gestures towards some of the characteristics of her speech in the "in vita" sonnets. It is connected not with the intellectual or rational but with the emotive. And it is constructed as a precious aesthetic object. In Poem 200, for example, her mouth is described as "di perle / piena et di rose, et di dolci parole" (200.10-I I; "full of pearls and roses and sweet words"). While the pearls and roses gracefully signal anatomical features, they also serve to categorize the words less as intellectual counters than as beautiful natural objects. They are yet another ornament for a body con-

${ }^{76}$ Oscar Büdel, "Illusion Disabused: A Novel Mode in Petrarch's Canzoniere," in Francis Petrarch, Six Centuries Later: A Symposium, ed. Aldo Scaglione, North Carolina Studies in the Romance Languages and Literatures: Symposia, 3 (Chapel Hill and Chicago: University of North Carolina Press and Newberry Library, 1975), p. I35. 
structed in terrns of adomments of all sorts. (Petrarch's heir Bembo was to describe a woman's speech, like the teeth through which it issues, in terms of pearls, and Petrarchan poems as well as their counterdiscourses recur to the figure too.) But whereas the aestheticization we examined earlier served to objectify and hence diminish the woman, here its valuation is more complicated. One cannot simply maintain that the aestheticization is a ploy for silencing Laura under the guise of praising her, for her speech is repeatedly described in terms of its overwhelming effect on its primary listener. Similarly, the inhabitants of sixteenth- and seventeenth-century England, schooled as they were in the precepts of classical rhetoric, were far less likely than contemporary critics to associate the aestheticization of speech merely with objectification and diminution. Laura's pearls, like those of some of her English counterparts, are as powerful as bullets, invisible or otherwise.

Or, to put it another way, in certain respects Laura's speech in the "in vita" sonnets is located in the semiotic, not the symbolic, though it also gestures towards the complexities of those categories and the problems of applying them to premodern texts. Repeatedly associated with the breeze, it is a natural force. Frequently linked to her songs and sighs, in a sense it is described in terms of prelinguistic impulses. (Indeed, while SturmMaddox, one of the relatively few critics who discusses Laura's speech in any detail, draws attention to distinctions between Laura's speech and her songs, the text itself tends to merge, not distinguish, the two modes of communication. $)^{77}$ But Julia Kristeva's warnings against neat separations and facile genderings of the symbolic and semiotic and against assuming the privileging of the one over the other are nowhere more germane than here. ${ }^{78}$ Male speech, even when it has the qualities usually attributed the symbolic, is by no means always a marker or source of power in this sequence. Nor is it always associated with positive qualities. Conversely, in the "in vita" sonnets Laura's semiotic speech has both the power and the agency that many paradigms, feminist and otherwise, would associate only with the symbolic.

These patterns are further confounded by the "in morte" sonnets. Laura's speech changes in several ways. Whereas it is sometimes, as before, described in aesthetic terms and constructed as gestural, by and large it is now represented through direct discourse, with its ethical content emphasized.

77Sara Sturm-Maddox, "Petrarch's Siren: 'Dolce Parler' and 'Dolce Canto' in the Rime sparse," Italian Quarterly, I03 (1986), 5-19; see also the later version of this argument in Sturn-Maddox, Petrarch's Laurels, pp. 46-62.

${ }^{78}$ Julia Kristeva, Revolution in Poetic Language, trans. Margaret Waller (New York: Columbia University Press, 1984), pp. 23-24. 
Like Beatrice, whom she increasingly resembles as the sequence progresses, in this group of poems Laura takes responsibility for the spiritual salvation of her lover. Here she instructs, warns, threatens. In particular, she repeatedly admonishes Petrarch about the dangers of Petrarchism itself; hence, like Watson's Echo and many other women in the sonnet tradition, she herself represents a type of counterdiscourse. ${ }^{79}$ In so doing, Laura, again like Beatrice, may recall the Greek and Hebraic traditions of the figure of Wisdom, who was often, though not invariably, gendered female. ${ }^{80}$ And yet at the very point where she seems to have the most agency, Laura's power is the most delimited, for there is no question but that she is a mediator expressing the wisdom of God and of a patriarchal order. She is at most a law clerk recording and repeating the Law of the Father.

In short, Laura's speech, like Petrarch's, is constructed in contradictory ways; her voice is associated with power and powerlessness, with cruelty and kindness, with divine wisdom and all too human temptation. If $\mathrm{Pe}-$ trarch wants to suppress and distance her speech, he wants to celebrate it as well. Sometimes the contradictions stemming from these divided visions generate contradictions within a single poem, as when Laura's speech is labeled with the diminutive "parolette" (253.I; "little words") yet also described as "accorte" ( $\mathrm{I}$; "eloquent") and associated with "chiuso inganno" (7; "loving deceptions") ${ }^{81}$ But most of the time Petrarch attempts to resolve his conflicting responses to woman's speech through a strategy we will encounter repeatedly in the discourses and counterdiscourses of English Petrarchism. That is, by distinguishing Laura's voice in the "in vita" and "in morte" poems, he recasts synchronic complexity as diachronic diversity: rather than acknowledging that female speech, like woman herself, can be both semiotic and symbolic, he creates a narrative in which it switches chronologically from one to the other. Thus he unties the oxymoron. This strategy for attempting to control conflict, which might be termed narrative displacement, is common in both the discourses and the counterdiscourses of English Petrarchism.

Hence reading the Rime sparse impels us to ask certain questions of English Petrarchan texts and also of the theoretical models to which they bear

\footnotetext{
${ }^{79}$ Ilona Bell also suggests that the female critique of love language represents an alternative to traditional Petrarchism which she terms Elizabethism ("Passion Lends Them Power: The Poetry and Practice of Elizabethan Courtship," esp. chap. 2, forthcoming); her interpretations of Laura's speech, however, differ significantly from mine.

${ }^{80}$ On Wisdom, see John Donne, The Anniversaries, ed. Frank Manley (Baltimore: Johns Hopkins University Press, 1963), pp. 20-40.

${ }^{81}$ I am indebted to Robert Rodini and Marguerite Waller for useful discussions of this passage and to Christopher Kleinhenz for additional assistance with Italian translation.
} 
such an uneasy relationship. Should one assume that speech and power, or, more specifically, speech and agency, are necessarily linked? Under what circumstances and to what extent can silence itself be a form of power? ${ }^{32}$ What are the connections between the poet's valuations of his own speech and that of the woman? And how do these problems contribute to the popularity of Petrarchism and its counterdiscourses? As these queries would suggest, the assumption that Petrarchism exemplifies masculine expressivity and female silence is very problematical ${ }^{83}$ for example, male subjectivity in these sequences is often rooted as much in the difficulty of speaking or writing as in the act of doing so, while to describe the female voice as silenced is to impose a teleological model on a process of incessant struggle.

At their best, feminist discussions of speech and silence have been exemplary in their subtlety: witness Margaret Homans's anatomy of the process she terms "bearing the word" or Margaret Higonnet's discussion of suicide as a type of speech, among other examples. ${ }^{84} \mathrm{~A}$ few more recent analyses of female agency in early modern texts have questioned the assumption that women's voices are erased, ${ }^{85}$ and other feminist books, notably the work of Patricia Yaeger, have refuted some common assumptions about the silencing of women in nineteenth- and twentieth-century texts. ${ }^{86}$ Such studies could serve as models for the much needed reinterpretation of both female and male speech in Petrarchism. Trenchant discussions like these have, however, coexisted with a curiously uncritical return to a type of positivistic social history. In particular, many otherwise acute scholars continue to repeat the bald assertion that women were silenced in early modern England, neglecting the complexities that we have been tracing. Studying English Petrarchism impels us variously to nuance and to negate that assertion.

But however one adjudicates these issues about gendered speech, ex-

${ }^{82}$ This and other questions about speech and silence are discussed, though from perspectives different from mine, in the incisive essay by Jonathan Goldberg, "Shakespearean Inscriptions: The Voicing of Power," in Shakespeare and the Question of Theory, ed. Patricia Parker and Geoffrey Hartman (London: Methuen, 1985); and Mary Ann Radzinowicz, "The Politics of Donne's Silences," John Donne Joumal, 7 (1988), I-19.

${ }^{83}$ A different challenge to that position appears in Bell, "Passion Lends Them Power."

${ }^{84}$ Homans, Bearing the Word; and Margaret Higonnet, "Speaking Silences: Women's Suicide," in The Female Body in Westem Culture: Contemporary Perspectives," ed. Susan Rubin Suleiman (Cambridge: Harvard University Press, 1986).

${ }^{85}$ See, e.g., Mary Beth Rose's observations about heroic drama in " "The Observed of All Observers': Gender and the Performance of Heroic Identity in Marlowe and Jonson," paper delivered at the 1994 Shakespeare Association of America meeting, Albuquerque, New Mexico.

${ }^{86}$ Patricia Yaeger, Honey-Mad Women: Emancipatory Strategies in Women's Writing (New York: Columbia University Press, 1988). 
amining the ways Petrarchism constructs the female in general and the Petrarchan mistress in particular guides us towards further explanations for its appeal in England. Although some critics have argued that patriarchy either changed little in the course of that century or veered towards more intense repression, ${ }^{87}$ in fact it was struggling with only partial success to contain rival social practices about marriage and the family and alternative ideologies about gender ${ }^{88}$ (Some have even argued for the appearance of a protofeminism both in England and on the Continent.) ${ }^{89}$ Gynecological treatises, for example, were far less uniform than Thomas Laqueur has encouraged us to believe; ${ }^{90}$ on the issue of heredity, say, they variously attribute all power to the male seed, declare that the mother's seed is more likely to determine characteristics of a female child than a male, explain that the mother may influence the traits of a child of either sex only if the sperm is weak, and so on. Similarly, marriage manuals and sermons disagree among and even within themselves on questions ranging from what constitutes a valid marriage to how much power the wife should have in running the family. ${ }^{91}$ There is some evidence that tensions about gender, particularly the problems of androgyny, intensified towards the end of the sixteenth and beginning of the seventeenth centuries. ${ }^{92}$ During the English Renaissance, then, the discourse of patriarchy was in fact multivocal and cacophonous, including as it did a series of conflicting discourses that compromise the very use of that noun.

Recognizing those conflicts helps us to understand the dual attraction of Petrarchism in England. First, in some respects it offered a monolithic image - the Petrarchan mistress is unfailingly beautiful - whose simplicity appealed at a time when many issues about gender were problematical. If, as Mario Praz observes, the discourse was almost as conventional as Byzantine painting, ${ }^{93}$ in a sense that intensified its attraction: the assurance that in

${ }^{87}$ See, e.g., Lisa Jardine, Still Harping on Daughters: Women and Drama in the Age of Shakespeare (Sussex, Eng.: Harvester Press, 1983).

${ }^{88}$ For a lengthier exposition of this argument, see Heather Dubrow, $A$ Happier Eden: The Politics of Marriage in the Stuart Epithalamium (Ithaca: Cornell University Press, 1990), esp. chap. I.

${ }^{89}$ See esp. Constance Jordan, Renaissance Feminism: Literary Texts and Political Models (Ithaca: Cornell University Press, 1990).

${ }^{90}$ See Thomas Laqueur, Making Sex: Body and Gender from the Greeks to Freud (Cambridge: Harvard University Press, 1990); and Laqueur, "Orgasm, Generation, and the Politics of Reproductive Biology," Representations, no. I4 (I986), I-4I.

${ }^{91}$ Compare Dubrow, $A$ Happier Eden, esp. pp. 5-27; and Mary Beth Rose, The Expense of Spirit: Love and Sexuality in English Renaissance Drama (Ithaca: Cornell University Press, 1988), esp. chap. I. Rose's treatment of the question, unlike mine, posits a clear movement towards an idealized Protestant model of marriage despite this variety.

${ }^{92}$ Rackin, "English Renaissance Stage."

${ }^{93}$ Mario Praz, The Flaming Heart: Essays on Crashaw, Machiavelli, and Other Studies in the 
England in, say, I 594 women could be praised in the same terms Petrarch had deployed in a different century and Ronsard had used in a different country offered a comforting alternative to changing and conflicting social norms connected with gender. On another level, however, Petrarchism flourished in that milieu less because it offered a model for a normative woman than because, like the rest of the culture, it staged a struggle to establish norms in the face of contradictions. And if English Petrarchism at once replicates and rejects cultural contradictions about gender, its counterdiscourses often do so as well.

Studies have asserted that in many respects gender is constructed between and among men, ${ }^{94}$ a claim I will variously develop and challenge. But for now we can observe that Petrarch's poetry provided English poets not only with a model, however difficult to interpret, for male-female interactions but also with a paradigm of one important manifestation of diacritical desire, the relationship between men, especially male rivals. For desire in Petrarch is, as I have stated, linked to and even enabled by a diacritical response to other men and even to earlier versions of oneself. While the Rime sparse incorporates a number of texts inspired by male friendship and political allegiance, such as the poems conceming Giovanni Colonna, its subtext is a relationship between men based on repudiation rather than affinity. Similarly, for all their imitativeness, Petrarch's followers often emphasize their rejections of other Petrarchan poets; witness the edginess in the preface to the second edition of Olive when Du Bellay answers imputations of slavish imitation. (Twentieth-century critics are not necessarily immune to the attractions of a similar ideal. Notice how J. W. Lever, whose own work on the sonnet is pioneering in many positive ways, links English rejections of earlier Petrarchan models with male potency and then proceeds to make them seem both natural and inevitable, as descriptions of male potency are wont to do: "The Tudor poets were indeed true pioneers both in form and content, breaking a virgin soil on which, in the

Relations between Italian and English Literature from Chaucer to T.S. Eliot (Garden City, N.Y.: Doubleday, 1958), pp. 264-265.

${ }^{94}$ Two of the most influential statements of this position are Gayle Rubin, "The Traffic in Women: Notes on the 'Political Economy' of Sex," in Toward an Anthropology of Women, ed. Rayna R. Reiter (New York: Monthly Review, 1975); and Eve Kosofsky Sedgwick, Between Men: English Literature and Male Homosocial Desire (New York: Columbia University Press, 1985). 
fullness of days, the great Elizabethans were to raise their golden harvest." Throughout his study he also interprets the development of the sonnet as a nationalistic triumph curiously reminiscent of the Whig view of history. ( $^{95}$

That subtext of repudiating other writers structures the Rime sparse as a whole: as many critics have pointed out, Petrarch repeatedly defines himself in contrast to Dante. ${ }^{96}$ This agenda mirrors his diacritical construction of his own subjectivity: from the first poem onwards, the deictic contrasts between here and there and between then and now which are so characteristic of this text often take the form of contrasts between two stages in his own development. Later poets were to adduce this emphasis on repudiation and distinction to define their own relationship to Petrarch and to other Petrarchan writers. Reactions against Petrarch are not an occasional anomaly in French Petrarchism, critics of that tradition have demonstrated, but a central characteristic. 97 "There is nothing more quintessentially Petrarchan," Reed Way Dasenbrock observes, "than an attempt to go beyond Petrarchism." 98 While that attempt is by definition the drive behind antiPetrarchism, it is also, I maintain, not the least impetus behind apparently "straight" Petrarchism as well: this is one of many ways in which the two are allied and aligned and one of many reasons it can be harder to distinguish them than the label "anti-Petrarchism" might seem to suggest.

These contrasts between the then and there of earlier poets and the now and here of one's own verse have not gone unremarked or unexplained by previous critics. Petrarch's reactions to Dante, like the interplay in many other instances of literary imitation, can be fruitfully explicated in terms of the anxiety of influence; if Laura, who is sometimes presented in maternal terms, is threatening, so too are two fathers who oversee the sequence, the heavenly one whom Petrarch attempts to approach and the author of the Divine Comedy. Similarly, unease about the extent of their imitations sparks later Petrarchan poets to repudiate other practitioners of Petrarchism and thus stress their own originality. Any reader of epic knows that relationships with fathers and father surrogates are no less significant in the birth of a nation than in the development of its members, and diacritical desire can also be explained, of course, in familiar though still important nationalistic

${ }^{95} \mathrm{~J}$. W. Lever, The Elizabethan Love Sonnet, $2 \mathrm{~d}$ ed. (London: Methuen, 1966), p. 13.

${ }^{96}$ For discussions of this pattern, see two books by Sara Sturm-Maddox, Petrarch's Metamorphoses: Text and Subtext in the Rime sparse (Columbia: University of Missouri Press, 1985), esp. chaps. 3, 4, and Petrarch's Laurels; and Waller, Petrarch's Poetics and Literary History.

${ }^{97}$ Robert J. Clements, "Anti-Petrarchism of the Pléiade," MP, 39 (1941-1942), I 5-2 I; and Yvonne Hoggan, "Anti-Petrarchism in Joachim du Bellay's Divers Jeux Rustiques," MLR, 74 (1979), 806-819.

${ }^{98}$ Reed Way Dasenbrock, Imitating the Italians: Wyatt, Spenser, Synge, Pound, Joyce (Baltimore: Johns Hopkins University Press, 1991), p. 17. 
terms: distinguishing oneself from Petrarch and his Continental imitators is one way of both celebrating and stimulating national pride.99

Psychoanalytic criticism offers a different though not incompatible etiology for the distinctions so central to Petrarchism. Male development, according to a number of otherwise divergent models, is rooted in an act of separation from the mother. The cartographers of post-Freudian psychology provide a number of alternative mappings for that act: Lacan relates it to the passage between the Imaginary and the Symbolic, certain object relations psychologists focus on its different implications for male and female development, ${ }^{100}$ and Jessica Benjamin asserts that failure in differentiation generates a need to dominate. ${ }^{101}$ Hence, if one agrees that the drive towards differentiation from the mother is the cornerstone of male development, one might merely interpret the relationship between Petrarch and Dante, Sidney and Petrarch, or John Collop and Sidney as a redirection and reenactment of that drive.

But such an explanation, while true in part, begs several questions that deserve more scrutiny. Automatically attributing the relationship among Petrarchan and anti-Petrarchan poets to that drive assumes without debate the transcultural and transhistorical centrality of differentiation. There is in fact a persuasive case for positing its significance in the Tudor period in particular, though not necessarily in other eras and countries. This pattern is more likely to occur in a culture in which the divisions between male and female are at once sharply defined and seriously challenged, as was certainly the case in a nation ruled for some years by a queen and engaged with many forms of cross-dressing, and the influential work of object relations critics such as Coppélia Kahn and Carol Thomas Neely further substantiates the significance of differentiation in sixteenth- and seventeenth-century England. ${ }^{102}$ But even if one does accept that differentiation was significant in some form in that milieu, distinctions between what it

${ }^{99}$ Compare Christopher Kleinhenz's analysis of the urge to develop the sonnet as a uniquely Italian form ("Petrarch and the Art of the Sonnet," in Francis Petrarch, ed. Scaglione, esp. p. I79).

${ }^{100}$ The most seminal statement of this position is Nancy Chodorow, The Reproduction of Mothering: Psychoanalysis and the Sociology of Gender (Berkeley: University of California Press, 1978). Many psychoanalytic critics have developed the principles of object relations psychology; see, e.g., Coppélia Kahn, "Excavating 'Those Dim Minoan Regions': Maternal Subtexts in Patriarchal Literature," Diacritics, 12 (1982), 32-4I.

${ }^{101}$ Jessica Benjamin, "Master and Slave: The Fantasy of Erotic Domination," in Powers of Desire: The Politics of Sexuality, ed. Ann Snitow, Christine Stansell, and Sharon Thompson (New York: Monthly Review, 1983).

${ }^{102}$ See, e.g., Coppélia Kahn, Man's Estate: Masculine Identity in Shakespeare (Berkeley: University of California Press, I98I). 
might mean in twentieth-century America as opposed to sixteenth-century England must be addressed. And why is diacritical desire more intense in the sonnet form than, say, in pastoral? What are the connections between the drive to distinguish oneself from other men and the drive to pursue a woman?

Reinterpreting the psychoanalytic models of differentiation addresses all these questions. Although many critics have persuasively suggested that psychoanalysis should be historicized rather than rejected out of hand, that project is still in its early days. The suggestive but brief commentaries on the influence of wet-nursing on developmental psychology demonstrate one direction in which it might move. ${ }^{103}$ The uprooted and rerouted family structures of Tudor and Stuart England, however, offer an even more fruitful arena for pursuing such historicizing and thus rethinking the workings of differentiation both in the culture at large and in Petrarchism in particular. Donne, Herrick, and Jonson all lost their fathers early in childhood, a pattern that directs our attention to the frequency of parental loss and remarriage. ${ }^{104}$ It was especially significant in the lives of the writers and readers of English sonnets, for England endured a major mortality crisis in I 557-I 559. ${ }^{105}$ Although the death rate varied from one area of the country to the next, as was the case in mortality crises throughout the century, in many regions the toll was heavy, with, for example, about Io percent of the population of Stratford dying. ${ }^{106}$ Remarriage rates differ according to variables of gender and class, but remarriage within a few years was not uncommon, especially for widowers. ${ }^{107}$ Hence many members of the gen-

${ }^{103}$ See Janet Adelman, Suffocating Mothers: Fantasies of Matemal Origin in Shakespeare's Plays, "Hamlet" to "The Tempest" (New York: Routledge, 1992), pp. 4-5, 7.

${ }^{104}$ For a more detailed discussion of parental loss and its effects on family structure, see Heather Dubrow, "The Message from Marcade: Parental Death in Tudor and Stuart England," in Attending to Women in Early Modem England, ed. Betty S. Travitsky and Adele S. Seeff (Newark and London: University of Delaware Press and Associated University Presses, 1994).

${ }^{105}$ See E. A. Wrigley and R. S. Schofield, The Population History of England, 1541-1871: A Reconstruction (1981; rpt., Cambridge: Cambridge University Press, 1989); and Paul Slack, "Mortality Crises and Epidemic Disease in England, 1485-1610," in Health, Medicine, and Mortality in the Sixteenth Century, ed. Charles Webster (Cambridge: Cambridge University Press, 1979).

${ }^{106}$ See two articles by J. M. Martin, "A Warwickshire Market Town in Adversity: Stratford-upon-Avon in the Sixteenth and Seventeenth Centuries," Midland History, 7 (1982), 26-4I, and "The Parish Register and History," Wanvickshire History, 2 (1973-1974), 3-I 5. I am most grateful to the author for also making available to me his unpublished research on the parish registers.

${ }^{107}$ Remarriage rates have been extensively discussed by social historians. See, e.g., Vivien Brodsky, "Widows in Late Elizabethan London: Remarriage, Economic Opportunity, and Family Orientation," in The World We Have Gained: Histories of Population and Social Structure, 
eration born during the I 550 and I 560 grew up in what today would be called a blended family, with a stepparent and quite possibly step- and halfsiblings.

Analyses of these complex subjects need to be inflected to allow for differences in cultural attitudes to both death and family structure, and even then they should be parsed in conditionals, subjunctives, and interrogatives. But the significance of these family patterns, however provisionally it is analyzed, is documented by the many tracts, such as Gouge's marriage manual, Of Domesticall Duties, that warn in great detail about the problems involved in introducing a stepparent into a family. (Or, as Petrarch himself puts it in Twyne's sixteenth-century translation of his Phisicke against Fortune, "Who so having children by his first marriage, bringeth a Stepmother among them, he setteth his house afire with is [sic] owne handes."') ${ }^{108}$

More to our purposes here, however, the prevalence of the early modern version of blended families invites us to challenge models of differentiation. Varied though they are in other ways, these discussions of male development reveal their own paternity, traditional Freudianism, in their emphasis on infancy and childhood. But might not that initial process of differentiation from the mother have been complicated and perhaps compromised if one was distinguishing oneself from a stepparent, as could readily happen if the birthmother died in childbirth or shortly afterwards? And, more to the point, might not an alternative form of differentiation, defining subjectivity in contrast to a stepparent or stepsibling, have been quite as formative an experience, in part, perhaps, because it echoed and intensified incomplete versions of the differentiation of early childhood?

These processes of differentiation must also have complicated and often intensified the rivalries customarily present in the family romance. Recognizing this possibility again warns us against a mechanical and ahistorical application of psychoanalytic models and in so doing provides a further etiology for the competitiveness in the sonnets read and written by members of the generation who endured the mortality crisis of 1557-1559. Literary critics are sometimes too ready to assume that intragenerational tensions merely displace intergenerational ones; in this instance, it is more than possible that rivalries with a half- or stepsibling are echoed in the

ed. Lloyd Bonfield, Richard M. Smith, and Keith Wrightson (Oxford: Basil Blackwell, 1986); B. A. Holderness, "Widows in Pre-industrial Society: An Essay upon Their Economic Functions," in Land, Kinship, and the Life-Cycle, ed. Richard M. Smith (Cambridge: Cambridge University Press, 1984); and Barbara J. Todd, "The Remarnying Widow: A Stereotype Reconsidered," in Women in English Society, 1500-1800, ed. Mary Prior (London: Methuen, 1985).

${ }^{108}$ Petrarch, Phisicke against Fortune, trans. Thomas Twyne (London, I579), sig. Nviiiv. 
diacritical rivalry between poets of the same generation which is so characteristic of English Petrarchism. ${ }^{109}$

Familial patterns of differentiation also resemble the distinctions between self and Other which make up the foundations of nationalism, thus suggesting connections between the birth of a nation and the multiple rebirths of Petrarchism. In particular, the stepparent or stepsibling metaphorically echoes those who both were and were not part of the English family at the moment of rising nationalistic consciousness: the Scots, Irish, Welsh. Richard Helgerson opens his recent examination of English nationalism on the observation that a group of writers who were particularly engaged in nationalistic self-fashioning were all born between I 55 I-I $564 \cdot{ }^{110}$ It may be no accident that this generation witnessed the mortality crisis of I $557-1559$ and its aftershocks at close quarters: whether or not their own families suffered losses, they are likely to have been surrounded early in their lives by an unusually high percentage of blended families. For this generation of the I550s and I 560 , the process of distinguishing self and Other was enacted in two arenas: the nation and its microcosm, the family. Might the nationalistic construction of the Other have been sparked and shaped by its domestic equivalent and vice versa? Might the need to distinguish the self and the Other, especially the Other gendered female, have been especially intense in the type of uprooted families I am postulating? There is no clearer instance of the need to historicize psychological patterns-or of a more neglected imperative, the need to render historical patterns psychological as well, particularly by orchestrating family and cultural history.

In short, differentiation played a significant role in both familial and national dynamics of Tudor England, though not necessarily the role suggested by the paradigms of Freudian and object relations theory. Petrarchism was simultaneously attractive and threatening in sixteenth-century England, I maintain, because it offered both a reenactment of failed differentiation and a solution to it. We have repeatedly traced the elision between male and female, subject and object, in Petrarchan poetry. Paradoxically, the very discourse that aims to define male subjectivity does so in terms that subvert that aim: the activities constructed as prototypically male, notably the quest for Laura and the laurel, are precisely those pursuits that blur the line between male and female. For the devotee of erotic love

\footnotetext{
${ }^{109}$ Though the research of modern psychoanalysts cannot be uncritically adduced in studying the families of Tudor England, cf. Theodore Lidz's observation that interactions among siblings may be almost as important as Oedipal tensions (The Person: His Development throughout the Life Cycle [New York: Basic Books, 1968], pp. 218-219).

${ }^{110}$ Richard Helgerson, Forms of Nationhood: The Elizabethan Writing of England (Chicago: University of Chicago Press, 1992), p. I.
} 
as for the devotee of affective piety, gender lines break down, imprisoning the lover in a labyrinth of conflicting definitions of male and female. Petrarch, like his followers, is a prisoner of gender no less than a prisoner of sex.

Through its emphasis on differentiation as the defining characteristic of many male relationships, however, Petrarchism also offers a key to and an escape from that prison. The lover who is unable to ground his subjectivity in the differences between himself and Laura can ground it instead in those that separate him from Dante. He can, in other words, transpose into another arena his battle with his lady, his fair warrior, a battle whose outcome is as indeterminate as almost everything else in the sequence. His relationship with women is not the excuse for homosocial desire but rather the conundrum that necessitates and shapes his relationship with men; the male-female interaction is not erased. At the same time that he achieves differentiation in one arena, however, he keeps losing it in another: success and failure once again collide and elide. The counterdiscourses of Petrarchism in turn allow an even deeper and clearer version of this reactive differentiation. The availability of such opportunities for distinguishing self and Other, however compromised they might on occasion prove, is yet another reason both Petrarchism and those counterdiscourses enjoyed the extraordinary vogue they did.

\section{VIII}

We are now in a position, as it were, to merge some files and to prepare to load others-in a position, that is, to summarize observations about the appeal of Petrarchism and to begin to interpret the workings of its counterdiscourses. The popularity of both straightforward Petrarchism and its counterdiscourses, like so many other phenomena in literary and cultural history, is overdetermined, and the scholar who privileges a single explanation shows more about her or his own ideology than that of the culture. The broader etiologies that explain the vogue Petrarchism enjoyed on the Continent as well as in England, and in both the medieval period and later, certainly should not be rejected; as I suggested earlier, Leonard Forster is correct in connecting the tradition to the rise of the vernacular, Marotti is persuasive in linking it to the struggles of courtiership, and a culture that delighted in literary craft surely enjoyed the technical challenges of the sonnet. Similarly, anti-Petrarchism is clearly rooted partly in an international recoil from the affectations of Petrarchism; witness among a host of other examples Du Bellay's attacks in the poem whose two versions are 
entitled, respectively, "A une dame" and "Contre les Petrarquistes." But in explicating the appeal of both Petrarchism and its counterdiscourses, we also need to explore explanations that are related to-though not necessarily unique to-a particular country, a particular class, even a particular decade or generation. If the texts by Du Bellay to which I just referred level accusations that recur in counterdiscourses from different periods and countries, they are also connected to a local controversy, the so-called querelle des Amyes. ${ }^{111}$ Similarly, in some important respects both English Petrarchism and its challengers can best be understood when viewed in their native habitat, the culture of Tudor and Stuart England.

Pace Marotti, love is indeed love, and I have been demonstrating that Petrarchism was attractive in that culture partly because its ambivalences about gender, desire, and their embodiment in the Petrarchan mistress enact cultural anxieties about those subjects. But the tradition drew on and contributed to conflicting constructions of male subjectivity as well. It typically emphasizes the struggles involved in establishing that subjectivity; in more senses than one, Petrarchism bodies forth the sujet en procès. In particular, medieval descriptions of desire interpellated the lover into the prototypically female position of the bride awaiting the arrival of the bridegroom, and as we will see, secular ideologies also established Petrarch's Renaissance counterparts in a role generally gendered female. Yet because in another sense the Petrarchan lover was a prototypically male role, those gender categories were confounded. Furthermore, the elision between the roles of lover and beloved which is so characteristic of Petrarchism blurred what was left of the boundaries between male and female. Displaying its own version of cross-dressing, Petrarchism both explicated and intensified the concerns about gender categories that characterized the end of the sixteenth century in England. The appeal of anti-Petrarchism stems in part from its attempts to reestablish firm definitions of gender.

At the same time, as we have observed, Petrarchism replicates and redefines many cultural problems unconnected or only partly connected to gender, such as the dangers of repetition and the slippery paths between success and failure and between agency and passivity, the latter pairing being often but not invariably one manifestation of the former. Once again the discourse involves continuing struggles and a sujet en procès. Petrarchism shapes and is shaped by cultural tensions in these arenas. Its counterdiscourses often attempt to resolve those tensions more definitively, only

${ }^{111}$ For a useful summary of that literary controversy, see $A$ New History of French Literature, ed. Denis Hollier et al. (Cambridge: Harvard University Press, 1989), pp. I88-I89. 
to end up replicating them. Their authors play fort-da without ever winning.

These replications of cultural tensions suggest further parallels with film theory, a field that has already interacted with feminist criticism in so many ways. To understand Petrarchism more fully, literary critics should foster in their own discipline a shift comparable to one in film studies. The highly influential model that Laura Mulvey established in "Visual Pleasure and Narrative Cinema," with its emphasis on monolithic male power and the erasure of female subjectivity, ${ }^{112}$ was soon nuanced by some critics, including Mulvey herself, and challenged by others. ${ }^{113}$ Just as certain film critics have come to argue that male subjectivity is neither assured nor monolithic, so critics of Petrarchism need to emphasize the ways both Petrarchism and its counterdiscourses pivot on unresolved struggles about both male and female gendering. To be sure, in Petrarchism as in Hollywood films, male power is preserved in many important ways. It is still the male poet who creates the sequence and literally and metaphorically utters its last word, and still the discourses of patriarchy that he often speaks, much as both the diegetic authoritative voices and the voice-over in Hollywood films are male. ${ }^{114}$ Yet Petrarchism, like many of the films in question, more frequently reenacts the struggles that compromise male power, whether represented by a single lover or by patriarchy itself, than it protects that power from threats. Those and many other struggles, as we will now see, sparked the growth of the counterdiscourses of English Petrarchism and, paradoxically, were replicated within them.

${ }^{112}$ Laura Mulvey, "Visual Pleasure and Narrative Cinema," Screen, I6 (1975), 6-I8; reprinted in Women and the Cinema, ed. Karyn Kay and Gerald Peary (New York: E. P. Dutton, 1977).

${ }^{113}$ See, e.g., Laura Mulvey, "Afterthoughts on 'Visual Pleasure and Narrative Cinema' Inspired by Duel in the Sun," Framework, 6 (198I), 69-79; Tania Modleski, The Women Who Knew Too Much: Hitchcock and Feminist Theory (New York: Methuen, 1988); and Linda Williams, "When the Woman Looks," in Re-Vision: Essays, in Feminist Film Criticism, ed. Mary Ann Doane, Patricia Mellencamp, and Linda Williams (Frederick, Md.: University Publications of America, 1984).

${ }^{114}$ See two studies by Kaja Silverman, "Dis-Embodying the Female Voice," in Re-Vision, ed. Doane, Mellencamp, and Williams, and The Acoustic Mirror: The Female Voice in Psychoanalysis and Cinema (Bloomington: Indiana University Press, 1988). 